\title{
Arşiv Belgelerine Göre Hasköy’ün Günümüze Ulaşamayan Ermeni Eğitim Yapıları
}

\section{Hasköy's Vanished Armenian Education Buildings in Archival Documents}

\author{
Teni Kiremitçiyan ${ }^{1}$ (D)
}

${ }^{1}$ Sorumlu yazar/Corresponding author: Teni Kiremitçiyan (Araş. Gör.),

Mimar Sinan Güzel Sanatlar Üniversitesi, Fen-Edebiyat Fakültesi, Sanat Tarihi Bölümü, İstanbul, Türkiye

E-posta: teni.kiremitciyan@msgsu.edu.tr ORCID: 0000-0002-7116-9677

Başvuru/Submitted: 15.12.2019

Revizyon Talebi/Revision Requested: 20.04.2020

Son Revizyon/Last Revision Received: 23.04.2020

Kabul/Accepted: 27.04 .2020

Online Yayın/Published Online: 30.06 .2020

Atıf/Citation: Kiremitciyan, Teni, “Arşiv Belgelerine Göre Hasköy'ün Günümüze Ulaşamayan Ermeni Eğitim Yapıları". Sanat Tarihi Yıllığı - Journal of Art History 29 (2020), 145-169. https://doi.org/10.26650/sty.2020.008
Öz

Osmanlı'da 19. yüzyılın resmî politikası olan modernleşme ile başlayan askerî, hukukî ve bürokratik tanzimin kökleşebilmesi, eğitimde yapılan reform ve kurumsallaşmaya dair atılımlar ile gerçekleştirilmişti. Her ne kadar Tanzimat Fermanı́nın (1839) esasları içerisinde net bir dille yer almasa da eğitim, Memâlik-i Âl-i Osman içerisinde bilhassa Islahat Fermanı (1856) ve de Osmanlıcılık ideolojisinin yayılımıyla ciddî dönüşümler geçirmiş, ıslah edilerek teşkilâtlandırılmaya başlanmıştı. Yaklaşık aynı tarihlerde Ermeniler arasında da kilisenin oligarşik gücü, seküler aydın bir topluluğun cemaat içerisinde söz sahibi olmaya başlamasıyla sarsılmış, böylelikle modern okullaşma hareketleri ivme kazanmıştı. Öncesinde, kimi münferit atılımlar haricinde, ruhban kesim tarafından yürütülen Ermeni eğitimi, 1853 yılında "Maârif Komisyonu"nun [Usumnagan Khorhurt] kurulması, ardından 1863 yılında Nizâmnâme-i Milleti Ermeniyân'ın ilân edilmesiyle cemaat içerisinde toplumsal bir sorumluluk haline gelmişti. Bu doğrultuda makale, 19. yüzyılda İstanbul'un en önemli Ermeni yerleşimlerinden biri olan Hasköy'ün, dönemin okullaşma hareketlerinde nasıl öncü bir konuma sahip olduğunu; arşiv belgeleri, inşa ve tamir süreçlerine dair yazışmalar ve fotoğrafların yardımıyla bugün var olmayan üç eğitim yapısı üzerinden okumaya çalışmaktadır. Biri harap olması, ikisi 1969 yılında çıkarılan istimlâk kararı sonucu yıktırılan bu yapıların araştııımasıyla anlaşılmıştır ki modern eğitime geçişte önemli olan bu üç okul, salt işlevsel özelliklerinin yanında -halen olduğu gibikültürel hafızanın önemli bir parçasını oluşturmaktadır.

Anahtar kelimeler: Hasköy, Eğitim yapıları, Ermeni kültürü, Osmanlı modernleşmesi

\section{ABSTRACT}

In the Ottoman Empire, the military, judicial, and bureaucratic adjustments that started with modernization as the official policy of the 19th century, became established through educational and institutional reforms. Although not clearly included in the Tanzimat Edict (1839), education underwent serious transformations and started to be institutionalized by means of the Reform Edict (1856) and the dissemination of Ottomanism in Memâlik-i Âl-i Osman. At approximately the same time, the oligarchic power of the Church over the Armenians was shaken with the rise of the secular intelligencia, as a result of 
which modern schooling movements gained momentum. The Armenian education, previously carried out by the clergy, became a societal responsibility within the community through the establishment of the Education Commission [Maârif Komisyonu, Usumnagan Khorhurt] in 1853 and with the declaration of Nizâmnâme-i Milleti Ermeniyân in 1863. The article discusses how Hasköy, an important Armenian settlement in Istanbul in the 19th century, led the schooling movements of the period and studies three vanished educational structures using correspondence on construction and repair, and photographs preserved in the archives. Three schools, one demolished because of its ruinous condition and two others as a result of an expropriation decision in 1969, played an active role in the transition to modern education and are still important elements in the cultural memory.

Keywords: Hasköy, Educational buildings, Armenian culture, Ottoman modernization 


\section{Giriş}

Osmanlı kültürünün ortaklarından biri olan Ermenilerin İstanbul'da kitleler halinde yaşamaya başlamaları şehrin fethinden sonraki iskân politikaları neticesinde gerçekleşmişti. Şehre göç ettirilen Ermeniler başta Kumkap1, Samatya, Yenikap1, Narlıkapı, Edirnekap1 ve Balat olmak üzere altı semte iskân ettirilmiş, ${ }^{1}{ }^{19}$. yüzyıla doğru Hasköy de dahil olmak üzere İstanbul'un çeşitli semtlerine yayılarak ikâmet alanlarını ciddî oranda genişletmişlerdi.

19. yüzyılda sahip olduğu binden fazla Ermeni hane ve nüfusu; dinî, eğitsel, düşünsel ve sanatsal verimliliği ile bir zamanlar İstanbul'un önde gelen semtlerinden olan Hasköy'e veya dönemin yerel halkının adlandırmasıyla Hayküğ'a [Ermeni Köyü] Ermenilerin yerleşimi ilk kez 17. yüzyılın başlarında Eğin'den [Agın] gelen göçmenlerle gerçekleşmişti. ${ }^{2}$ Yaklaşık yirmi hane olan bu göçmenler önce Bademlik'e yerleşmiş, daha sonra Karaağaç’ta ${ }^{3}$ satın aldıkları arsaya kurdukları tuğla ve kiremit harmanı sayesinde edindikleri yüklüce sermaye ile de semtin refahını arttırmışlardı. ${ }^{4}$

18. yüzyılın başlarına kadar hem imparatorluk nezdinde eğitimi merkezîleştirmekten mesul bir kurum bulunmaması hem de din ve tedrisatın birbirinden bağımsız düşünülmemesi sebebiyle, Ermenilerde eğitimin idaresindeki tek yasal yetkili kurum, Tanzimat ve sonrası döneme kadar, Patriklik'ti. Bu nedenle cemaat çocuklarının eğitimi ya kiliselerin içerisinde uygun görülen bir mekânda ya da -Hasköy'de de örneği görüldüğü üzere ${ }^{5}$-ruhban sınıfından kimselerin mektebe çevirdikleri şahsî konutlarında, dinî eğitim ya da okuma-yazma öğretilmesi üzerinden sağlanmaktaydı. Fakat 19. yüzyılın başından itibaren Ermenilerin eğitim politikasındaki din ağırlıklı geleneksel yapı, yerini yavaş yavaş seküler "yeni bir tarza" bırakmış, bu bakışla da eğitim veren okullar yüzyılın ortalarına doğru süratle çoğalmıştı.

Ermeni okullarında başlayan bu değişim sadece geleneksel yapının yerine yeni kurumların oluşumundan ibaret değildi. Seküler eğitim veren Ermeni okullarının çoğalmasındaki en büyük etken öncelikle Ermenilerin Avrupa ile kurdukları ticarî ağ sayesinde var ettikleri “burjuva/orta sınıf” ailelerin ortaya çıkışı ve bu ailelerin ardıl kuşaklarını Paris ve Venedik'teki Ermeni kolejleri ile Avrupa'daki üniversitelere göndermeleriydi. Avrupa'daki -özellikle 1848 Ayaklanması sonrası yayılan- liberal düşünceler doğrultusunda demokrasi, anayasa ve

1 Vartan Artinian, Osmanlı Devleti’nde Ermeni Anayasası'nın Doğuşu 1839-1863, Çev. Zülal Kılıç, Aras Yayıncılık, İstanbul, 2004, s.18-21; Davut Kılıç, Osmanlı İdaresinde Ermeniler Arasındaki Dinî ve Siyasi Mücadeleler, Avrasya Stratejik Araştırmalar Merkezi Yayınları, Ankara, 2000, s.48.

2 Eremya Çelebi Kömürcüyan, İstanbul Tarihi, XVII. Asırda İstanbul, Çev. Hrans D. Andreasyan, Haz. Kevork Pamukciyan, Eren Yayıncılık ve Kitapçılık, 1988, s.201.

3 Bahsi geçen her iki yer de mahalle adıdır. Günümüzde Bademlik ismi güncelliğini korumakla birlikte; Karaağaç, Örnektepe Mahallesi olarak anılmaktadır.

4 Kemahlı Krikor, Jamanagakrutyun [Kronoloji], Haz. Mesrop Nışanyan, Ermeni Apostolik Kilisesi S. Hagop Matbaası, Kudüs, 1915, s.190; Todün, "Krikor Baronderi Hişadagaranı, Balati S. Hıreşdagabed Yegeğetsiin Artiv" [Krikor Baronder'in Anıları, Balat'taki Surp Hıreşdagabed Kilisesi Vesilesiyle], Panaser, C.II, S.3-4, 1901, s.152.

5 Hasköy'deki Istepanos Şapeli’nde görevli Rahip Haçadur'un, 10 Temmuz 1703 tarihinde Abdüsselâm Mahallesi'nde bulunan kendi ikâmetgâhındaki Surp Yeğya [Aziz Yahya] adına ithaf edilen şapelin inşasını tamamlayarak hem Ermeni çocuklarının eğitimini sağladığı hem de halka din alanında önderlik ettiği bilinmektedir. 
aydınlanma fikirleriyle donatılmış bu kesim, memleketlerine döndüklerinde milletin, özellikle kilisenin oligarşisinden sıyrılması ve ilerlemesi için gerekli olan Batı modelli modern bilgiye vâkıf işgücünü sağlamak maksadıyla bir eğitim seferberliği başlatmışlardı. Bu seferberlikteki ilk ve en önemli adım 22 Ekim 1853'te Patriklik bünyesindeki Cismanî Meclis tarafından oluşturulan "Maârif Komisyonu”na [Usumnagan Khorhurt] aralarında Hassa Mimarı Nigoğos Balyan'ın (1826-1858); mühendis Arakel Sisag (1820-1886), Artin Paşa (Harutyun Karekin) (1830-1901) ve mühendis Simon (1834-1890) Dadyanlar'ın; hukukçu ve yazar Krikor Odyan'ın6 (1834-1887); hekim, şair, yazar ve tercüman Nahabed Rusinyan'ın (1819-1876); hekim, yazar, pedagog Dr. Serovpe Viçenyan'ın (Serviçen) (1815-1897) bulunduğu toplam on dört sivil üyenin atanmasıyla atılmıştı. Komisyon; eğitimi iyileştirme, denetleme, standartlaştırma, finanse ve teşvik etmenin yanı sıra Ermeniler arasında yaygınlaştırmayı, dilsel reformu sağlayarak klasik Ermeniceden [krapar] ziyade çağdaş Ermenicenin [aşkharhapar/jamanagagits] kullanımına olan eğilimi arttırmayı ve yeni açacağı okullarda millî gelenek ve ahlâka uygun entelektüel bir neslin yetiştirilmesini hedeflemekteydi. ${ }^{7}$

Komisyonun varlığı çok uzun sürmemiş olsa da amaçlarını kamuya duyurmayı başarmış, modern ve sivil eğitimin Ermeniler nezdinde öneminin anlaşılarak 1863 yılında ilân edilen Nizâmnâme-i Milleti Ermeniyân ${ }^{8}$ içerisinde maddeleştirilmesine ${ }^{9}$ ve hedeflediği ilkeler doğrultusunda İstanbul'da pek çok yeni okulun kurulmasına vesile olmuştu. ${ }^{10}$

6 Hem Nizâmnâme-i Milleti Ermeniyân'ın hem de Kânûn-1 Esâsî’nin hazırlanmasında büyük katkıları olan Krikor Odyan hakkında ayrılı bilgi için bkz. Silvart Malhasyan, "Odyan, Krikor", Osmanlılar Ansiklopedisi, Yaşamları ve Yapıtlarıyla, C.II, Der. Ekrem Işın, İsmail Kara, Yapı Kredi Yayınları, İstanbul, 2008, s.375.

7 Komisyonun diğer üyeleri: Hagop Amasyan (ziraatçı, bürokrat; 1827-1895), Apraham Paşa Yeramyan (dilbilimci, devlet görevlisi; 1838-1918), Garabed Ütücüyan (gazeteci, 1823-1904), Harutyun Hovivyan (filolog), Sarim Maksudyan (dilbilimci), Haçadur Bardizbanyan (eğitmen; 1809-1856), Hovhannes Vahanyan (kimyager, ö. 1891). Arşag Alboyacıyan, "Gırtagan Hisnamyag Mı (1853-1903) [Eğitimde Elli Y11], Püzantion, 27 Ekim 1903, s.1; Anonim, “Usumnagan Khorhurt” [Maârif Komisyonu], Arpi Araradyan, S.6, İzmir, Aralık 1853, s.73-74; Mağakya Ormanyan, Azkabadum [Milletnâme], C.III, Surp Hagopyants Matbaası, Yerusalem, 1927, sütun 2640.

8 Nizâmnâmenin orijinal metni için bkz. Anonim, Azkayin Sahmanatrutyun Hayots [Nizâmnâme-i Milleti Ermeniyân], Mühendisyan Matbaası, İstanbul, 1863. Metnin Türkçe çevirisi için bkz. Artinian, a.g.e., s.208264; metin hakkında ayrıntılı bilgi için bkz. Arşag Alboyacıyan, "Azkayin Sahmanatrutyunı, İr Dzakumı Yev Girargutyunı” [Millî Nizamname, Başlangıcı ve Tatbiki], Intartsag Oraytsuyts Azkayin Hivantanotzi 1910 [Ermeni Hastanesi Mufassal Takvimi], H. Madteosyan Matbaası, İstanbul, 1910, s.76-528.

9 Nizâmnâmenin ilgili maddesi: "Mearif Komisyonu beyanındadır. 45. Madde: Mearif komisyonu avamde ve erbabı meariftden olarak, yedi azaden mürekkeb olub, vakifesi Ermeni milletinin talim ve terbiyesine nazaret, ve millet mekteblerinin bir sureti muntazamede ve kız çocuklarının talim ve terbiyesi zımnında teşekkül iden şirketlere icrai teşvikat ve muvenet, ve mekteb hocalarının ıslahı ahvaline ve temini hali müstakbelleri ile ehl ve erbab hocalar yetişdirilmesine, ve mekyetibi mesküreye mahsus ders kitabları tedarik olınmasına ikdam ve zeyret itmek hususlarından ibareddir. Ve bu mekteblerde tahsili fûnun idenlere şahadetname itası ve ders kitablarının tayini ve imtihanı senevileri hususları mezkûr komisyon marifeti ile icra olınur. Fakat talimi mezhep idenlerin Meclis-i Ruhanî'den şahadetname almaları ve mezhep kitabları ile muallimleri hakkında Meclis-i mezkûre müraceat olınması iktiza eder. Ve talimi mezheb imtihanı dahi Meclis-i Ruhanî marifetiyle icra kolınur" (Anonim, Azkayin Sahmanatrutyun Hayots [Nizâmnâme-i Milleti Ermeniyân], s.29-30).

10 Louise Nalbandian, The Armenian Revolutionary Movement, The Development of Armenian Political Parties through the Nineteenth Century, University of California Press, 1963, s.46-52; Artinian, a.g.e., s.74-79, 84. İlerleyen zamanlarda da modern eğitimin önemi ve nasıl olması gerektiğine dair tartışmalar Ermeni aydınları 
19. yüzyıl başına gelinceye değin Hasköy’ün Ermeni cemaatinin giderek büyümesi, okullaşma ihtiyacını da beraberinde getirmişti. Karma ve seküler bir eğitime sahip Surp [Aziz] Nersesyan Mektebi; sadece himaye değil eğitim görevini de yerine getiren Kalfayan Kız Yetimhanesi ve de yüzyılın üçüncü çeyreğinde açılan Nubar-Şahnazaryan Mektebi sayesinde semt, İstanbul'un Ermeniler için önemli bir terakki ocağı haline gelmişti.

\section{Surp Nersesyan Mektebi}

Hasköy'de -yine günümüze ulaşamayan-Surp Istepanos Kilisesi’nin bitişiğine inşa edilen okulun ${ }^{11}$ kuruluş tarihi hakkında farklı fikirler mevcut olup, kimi kaynaklarda 4 Temmuz 1823 tarihinde Canik Amira, ${ }^{12}$ kiminde ise Mıgırdiç Amira Cezayirliyan ${ }^{13}$ (1805-1861) (F.1) tarafından 1836'da yaptırıldığ ifade edilmektedir. Ancak 1905'teki tadilat sonrasında yeniden inşa edilen okulun girişinde yer alan kitabesinde 1832 tarihi okunmakla birlikte herhangi bir baninin ismi yer almamaktadir.

19. yüzyılın başından itibaren Ermenilerin değişen eğitim politikası doğrultusunda kurulan modern okulların büyük çoğunluğunu, özellikle İstanbul dahilindekileri, sivil mesen olarak niteleyebileceğimiz amiralar finanse etmekteydi. Her ne kadar amiraların çoğunluğu, Ermeni milleti üzerinde kurdukları otoritenin paylaşıldığı gerekçesiyle liberal ve modern düşüncelerden hoşnut olmasalar da azınlıkta kalan bir kısmı, karşıt görüş sahibi kişilerle ittifaka girerek, eğitim alanındaki gelişmeleri desteklemişlerdi. ${ }^{14}$ Mıgırdiç Cezayirliyan da Surp Nersesyan Mektebi’nin

tarafından devam ettirilmiş, belirli periyotlarla düzenlenen toplantılar vesilesiyle konuya dair fikir birliğine ulaşılmaya çalışılmıştı. Ayrıntılı bilgi için bkz. Minas Çeraz, Azkayin Tasdiaragutyun: Varjabedagan Joğovi meç Khosuadz Carer [Millî Eğitim: Maârif Toplantısından Nutuklar], Aramyan Matbaası, İstanbul, 1873.

11 Genel olarak bakıldığında İstanbul' da kurulan Ermeni okullarının büyük çoğunluğunun, tıpkı camilerin yakınına kurulan medreselerde olduğu gibi, Ermeni kiliselerinin yakınına yahut kilise kompleksinin içerisine inşa edildikleri görülmektedir.

12 Genellikle devletin üst düzey görevlerinde yer alan Ermenilerin kullanabildiği bir unvan.

13 Aslen Eğinli olan İstanbul'un köklü sarraf ailesinden Sarkis Amira'nın oğlu Mıgırdiç Cezayirliyan, önemli şahsiyetlerin sarraflığı haricinde, ipekçilik ve ziraatın gelişmesi ile ilgilenmiş, aynı zamanda gümrük eminliği yaparak uzun yıllar devlet adına vergi toplamıştı. Eğitime ve sanata büyük önem veren Cezayirliyan Amira, pek çok öğrencinin ve sanatkârın hamiliğini üstlenmişti. 1859 yılında Cezayirliyan, hamisi Sadrazam Mustafa Reşid Paşa'nın aleyhtarları tarafından iftiraya uğramıştı. Amira, yolsuzluk yaptığı gerekçesiyle tüm mal varlığına el konulduktan kısa süre sonra da vefat etmişti (Vahan Zartaryan, Hişadagaran, Hay Yerevelineru Gensakrutyunnerı, Lusanıgarnerı, Tzerakirneri, Krutyunnerı Yevayln 1512-1912 [Hatırat, Ünlü Ermenilerin Biyografileri, Fotoğrafları, El Yazmaları, Yazıları vs.], C.II, Nışan-Babigyan Matbaası, İstanbul, 1910, s.25-28; Saro Dadyan, Osmanlı'da Ermeni Aristokrasisi, Everest Yayınları, İstanbul, 2011, s.157-160). Cezayirliyan hakkında ayrıntılı bilgi için bkz. Nursel Manav, Zenginlikten İflasa Mustafa Reşid Paşa'nın Sarrafı Cezayirlioğlu Mıgırdiç, Libra Kitap, İstanbul, 2019.

14 Ermeni milleti üzerindeki amiraların bu rolünü, yüzyılın ortalarından itibaren 'esnaf' adı verilen orta sınıf devralmıştı. Ayrıntılı bilgi için bkz. Artinian, a.g.e., s.37, 41-42, 66-67, 73, 96-99, 105; Hagop L. Barsoumian, İstanbul'un Ermeni Amiralar Sınıfı, Çev. Solina Silahlı, Aras Yayıncılık, İstanbul, 2013, s.138, 142-143, 148-149, 154-158. 


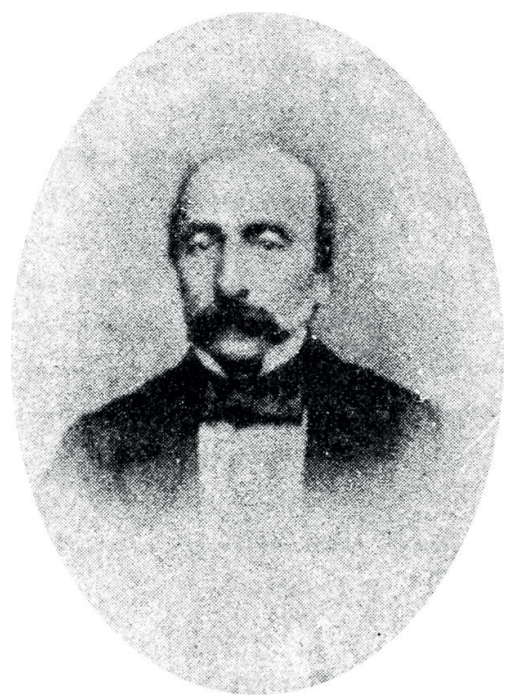

F. 1: Migırdiç Cezayirliyan (1805-1861)

(Anonim, Intartsag Oraytsuyts Azkayin Hivantanotzi 1910, s. 312.)

gelişiminde büyük etkisi ve emeği olan amiralardandı. Modern anlayışla kurulan diğer Ermeni okullarındaki gibi birincil amacı Ermeni milletinin entelektüel gelişimini sağlamak olan ${ }^{15}$ okulun ilk kadrosunda felsefeci ve eğitimci Fizika Boğos (Melikşahyan, 1788-1858); yazar, gazeteci, tercüman Hovsep Vartanyan (daha sonra Vartan Paşa, 1815-1879); Khosdovanahayr ${ }^{16}$ Kevork Ardzruni (1789-1894) gibi önemli hocalar; müfredatında ise Ermenice ve Türkçenin ${ }^{17}$ yanı sıra Fransızca ve İtalyanca gibi Batı dilleri ile ziraat, coğrafya gibi tabiat; fizik, cebir ve matematik gibi fennî dersler yer almıştı. ${ }^{18}$ Pera' daki Mekteb-i Tıbbiye-i Şâhâne'nin 1848 'de çıkan yangın sonrası Hasköy'deki Humbarahane'ye taşındığı dönemde okulun hocalarından Dr. Serovpe Viçenyan ve Dr. Istepan Paşa Aslanyan (1822-1902) da Cezayirliyan'ın ricası üzerine Surp Nersesyan Mektebi’nde gelerek dersler vermiş, aynı zamanda sağlık işleri ile de ilgilenmişlerdi. Okulun kadrosuna zaman içerisinde katılan diğer önemli eğitimciler arasında başta felsefe hocası Badveli ${ }^{19}$ Toros Zorayan gelmekteydi.

15 Anonim, “Azkayin Joğov Hayots” [Millî Ermeni Meclisi], Dzrakir Inthanur Orinats Azkayin Gırtutyan [Millî Eğitim Programı], M. Sarıyan, İstanbul, 1881.

16 Cemaatin günahlarını dinleyen papaz.

17 19. yüzyılda İstanbul'daki pek çok Ermeni okulunda Türkçe dersinin müfredatta yer aldığı bilinmektedir. Osman Ergin, Türk Maarif Tarih, C.I-II, Eser Matbaası, İstanbul, 1977, s.752-754.

18 Her ne kadar Ermeni okullarında bir modernleşme gerçekleşmişse de bu dinsel konulardaki eğitimin kaldırıldığı anlamına gelmemekteydi. Millî geleneklerin ve ahlakın da öğrencilere aktarılması esasına dayanan müfredat içerisinde din, müzik ve kilise tarihi gibi derslerin varlığı ya da kutsal günlerde dinî ritüellere katılma ile devam ettirilmiş, oluşturulan bu sentez ile bir denge sağlanmaya çalışılmıştı. İlkokul seviyesindeki Ermeni okullarında din bilgisinin yanında dilbilgisi, okuma, aritmetik, coğrafya ve tarih; ortaokullarda ise cebir, fizik, tarih, müzik, Türkçe ve Ermenice ile çeşitli Batı dilleri de okutulmaktaydı (Püzant Keçyan, Badmutyun Surp Pırgiç Hivantanotsin Hayots Gosdantinobolis, Azkayin Hüsnamya Nıgarakir [İstanbul Surp Pırgiç Ermeni Hastanesi’nin Tarihi], K. Bağdadlıyan Matbaası, İstanbul, 1887, s.109).

19 Ermenice ‘badveli’ kelimesi ‘büyük saygı̈ gören hoca’ anlamındadır. Aynı zamanda Protestan din adamlarından 
Badveli Zorayan, Armenolog ve filolog Madatya Karakaşyan'1 (1820-1903); edebiyat öğretmeni, şair ve tiyatro yazarı Tovmas Terziyan'1 (1840-1909); Türkolog Reteos Krikoryan'1 (Heretik Hoca) (1819-1904); matematikçi Simon Mikayelyan'1 tayin ettirerek Surp Nersesyan Mektebi'ni aydınların bir arada toplandığı şehrin ileri gelen Ermeni okullarından biri haline getirmişti. ${ }^{20}$

Maârif Komisyonu'nun amaçları arasında yer alan eğitimde eşitlik ilkesine uygun şekilde Surp Nersesyan Mektebi karma bir eğitime sahipti. Her ne kadar kız çocuklarının da eğitime dahil edilmesi kararlaştırılsa da bunun nasıl gerçekleştirileceği komisyonun ve tüzel kurumların düzenleme kılavuzlarında belirlenmediği için öğrenciler aynı okula devam etmiş; fakat erkekler ve kızlar ayrı sınıflarda eğitim görmüşlerdi.

Hakkında herhangi bir belge, çizim ya da fotoğrafa rastlanılmamış olmakla birlikte okulun ilk binasının yetmiş yılı aşkın süre faal olarak kullanıldı̆̆ı; fakat 1900'lerin başında köklü bir yenilenmeye ihtiyacı olduğu arşiv belgelerinden anlaşılmaktadır. Beyoğlu Mutasarrıfı imzalı ve Nisan 1904 tarihli bir belgeye göre; Hasköy'de yapımı planlanan Surp Nersesyan Ermeni Mektebi'nin inşasını, okulun eski mezunlarından banker Toros Efendi Parağamyan finanse etmiş, yaklaşık 1500 liralık da finansman sağlamıştı.

Tuğla tüccarı Şahbaz Efendi tarafından nezâret edilen söz konusu inşaat için Beyoğlu Mutasarrıfı resmî ruhsatın alınıp alınmadığının bilinmediğini belirterek, durumu Zaptiye Nezâreti'ne iletmişti. ${ }^{21}$ Bunun üzerine Zaptiye Nezâreti, Maârif Nezâreti'ne ruhsat durumunun bildirilmesi talebini içeren bir yazı göndermiş, ${ }^{22}$ Maârif Nezâreti'nin ilgili kaleminden belgenin arkasına düşülen notta geçtiği şekliyle:

“(...) kayda lede'l-mürâca'a mahal-i mezkûrda esâsen ruhsât-1 resmiyye gayr-i merbut ve zekûr ve inâsa mahsus bir ermeni mektebinin mevcud oldığ anlaşılmış ve fakat bu kere mekteb-i mezkûrun müceddeden inşâ olunacağına dâir Nezâret-i Celilelerine bir gûna mürâca'at vuku'bulmamış olduğına ve müceddeden mekteb inşâsı usûli dâiresinde vuku'bulacak mürâca'at üzerine icrâ-yı tahkikâtla"23

ruhsat için izin verilmek üzere padişaha durumun arz edileceği belirtilmişti. Esasen söz konusu yerde zaten erkek ve kız çocuklarına mahsus ruhsatsız bir okulun bulunduğu Maârif Nezâreti kayıtlarının incelenmesinden anlaşılmakla birlikte, söz konusu yeni inşaat için de nezârete hiçbir mürâcaat yapılmadığg söylenmişti. Ayrıca yeni bir okul inşası için, usûllere uygun bir mürâcaat yapılsa dahi konunun araştırıldıktan sonra ruhsat verilmesi için gerekli işlemlerin başlatılabileceği vurgulanmıştı. Konuya ilişkin bu bilgi, Maârif Nezâreti Mektûbî Kalemi’nden, Zaptiye Nezâreti'ne de aynı içerikle iletilmişti. ${ }^{24}$

da bu şekilde bahsedilir.

20 Varjabedyan, a.g.e., s.58, 60, 227. Açılışından itibaren aylık 10,000 kuruş değerinde bağış yapan Cezayirliyan Amira, öğrencilere ateist fikirler aşıladığı yönündeki söylentiler sonucu okuldan elini çekmişti.

21 BOA.Y.PRK.ZB.34.59.1.2 (Tarih: H. 4 S1322/M. 20 Nisan 1904).

22 BOA.MF.MKT.776.48.1.1 (Tarih: H. 8 S 1322/M. 24 Nisan 1904).

23 BOA.MF.MKT.776.48.1.2 (Tarih: H. 12 S 1322/M. 28 Nisan 1904).

24 BOA.MF.MKT.776.48.2.2 (Tarih: H. 16 S 1322/M. 2 Mayıs 1904). 
Yazışmalarda inşa edilecek okulun planına yer verilmiş olup, "Mühendis Mehmed Hâlid" imzalı pusuladaki ${ }^{25}$ ölçülerine göre yapı, "tûlen [boy] 40, 'arzen [en] 17 ve kadden [yükseklik] 17 zirâ'-1 [arşın] mi "mâri" ve toplam alan olarak da "680 zirâ"” idi. Adliye ve Mezâhib Nezâreti'ne Patrik Mağakya I. Ormanyan (1896-1908/d. 1841-ö. 1918) imzasılla gönderilen belgeye göre; ${ }^{26}$ Hasköy’ün Abdüsselâm Mahallesi’ndeki Ermeni Kilisesi'nin [Surp Istepanos] Nersesyan adlı karma okulu, zamanla harap olduğundan, yazı ekiyle gönderilen planda ${ }^{27}$ da gösterildiği üzere boyu 40, yüksekliği ve eni 17 zirâ'-1 atik ve kârgir yeni bir inşaat yapılacaktı (F.2) ${ }^{28}$ İnşa masrafı da 1700 lira olarak tahmin edilip, bu para da finanse edilmiş, son olarak ruhsat için gerekli işlemlerin yapılması istenmişti. Bu yazıdan hemen sonra Şehremâneti, Adliye ve Mezâhib Nezâreti'ne gönderdiği yazıyla okulun inşası konusunda herhangi bir mahzur olup olmadığını, inşa masraflarının ne şekilde karşılanmış olduğunun araştırıldığını aktarmışt1. ${ }^{29}$ Buna göre Şehremâneti, eski okulun gerçekten harap olduğundan yıkılarak yerine yeni bir okulun kârgir ve $680 \mathrm{~m}^{2}$ olacak biçimde inşa edilmesinde bir sakınca bulunmadığını, inşaatın finansmanının da Galata'daki Demir Han'da ikâme eden Toros Efendi Parağamyan ve kardeşleri Dikran ve Mihran efendiler tarafından sağlandığını Adliye ve Mezâhib Nezâreti’ne iletmişti. Ertesi gün Adliye ve Mezâhib Nezâreti yetkilileri, evrakları incelemiş ve konu hakkında kendi bakanlarına, ${ }^{30}$ bakan ise Sadâret'e durumu bildirmişti. ${ }^{31}$ Sadâret' in ilgili kalemi konuyu değerlendirerek:

“(...) mekteb-i mezbûrun inşâsı içün ruhsatı hâvi emr-i 'âli ısdâr olındığına dâir kayd bulunamamış ise de (...) zikr olunan mektebin harâb ve mâ'il-i inhidâm olmasına mebni hedm olunarak... müceddeden kârgir olmak üzere inşâ ve 'inde’t-tahmîn sarfı lâzım gelen bin yedi yüz liranın Galata da Temur handa mukim Paregamyan Toros Efendi ile biraderleri tarafından i'âneten tesviye ifâ idileceği ve mezkûr mektebin inşâsında bir gûna mahzur olmadığı anlaşılmış ve tahkikât ve iş‘ârât-1 vâk1'a muvâfık usûl ve imsâli bulunmuş olmasıyla hitâm-1 inşasıyla küşâdında ma'ârif-i 'umûmiye nizâmnâmesinin yüz yigirmi tokuzıncı maddesi ahkâmına muvâfik mu'âmele olunmak üzere zikrolunan mektebin inşâsı içün ruhsatı hâvi emr-i 'âli’’32

çıkarılması hususu Şurâ-yı Devlet'e sunulmuştu. Bu hususta, okulun inşaatı için ruhsat izni verildiğine dair bir kayıt bulunmadığı belirtilmiş; ancak eski okulun gerçekten kötü bir durumda bulunması, yeni inşaatın finansmanının da sağlanmış olması, okulun yapımında bir sakınca olmaması, ayrıca benzer durumların emsal örnekleri olması gibi birtakım nedenlerle, ruhsat çıkarılmak üzere onaya sunulmasına karar verilmişti. Şurâ-yı Devlet konuyu görüşerek, okulun

25 BOA.ȘD.2739.7.1.1 (Tarihsiz).

26 BOA.ŞD.2739.7.2.1 (Tarih: R. 26 Nisan 1320/M. 9 Mayıs 1904).

27 İnşası düşünülen okulun diğer tasnifteki planı için bkz. BOA.İ.AZN.57.8.2.1.

28 Mühendis Mehmed Hâlid imzalı pusuladaki ölçülerin yeri yanlış yazılmış olmalıdır; çünkü hem patriğin yazısında hem de plandaki ölçüler boyu 40, yüksekliği ve eni 17 zirâ‘'-1 atik şeklindedir.

29 BOA.ŞD.2739.7.3.1 (Tarih: R. 5 Mayıs 1320/M. 18 Mayıs 1904).

30 Belgede bankerin ismi 'Paregamyan Toros' olarak geçmektedir. Bkz. BOA.ŞD.2739.7.4.1 (Tarih: R. 6 Mayıs 1320/M. 19 Mayis 1904).

31 BOA.ŞD.2739.7.5.1 (Tarih: R. 10 Mayıs 1320/M. 23 Mayıs 1904).

32 BOA.ŞD.2739.7.6.1 (Tarih: R. 12 Mayıs 1320/M. 25 Mayıs 1904). 
planında ${ }^{33}$ gösterilen ölçüleri aşmamak, inşa masraflarının yetmemesi durumunda "kimseden cebren akçe ahzi gibi mugâyir-i rıâ" yani halktan zorla para toplamaya yeltenmemek, inşaat bitiminde yapılacak olan resmî açılışın, ilgili kanun maddesine uygun olarak yapılması gibi hususlara uyulması şartıyla, kararı sadrazama sunmuştu. ${ }^{34}$ Konuyla ilgili irade, okul inşaatına ruhsat verilmesi yönünde Ağustos 1904 itibariyle çıkmış, ${ }^{35}$ gerekli talimat Maârif Nezâreti’ne iletilmişti. ${ }^{36}$

Her ne kadar arşiv belgelerinde yapının mimarına dair bir kayda rastlanılmasa da Ermenice kaynaklarda Mimar Krikor Melidosyan'ın adı anılmaktadır. Sonunda büyükçe kârgir bina yükselmiş, okulun iç kısmının yapımı 1 Mayıs 1905'te sonlanmıştır.

Yazışmalarda yer verilen okulun planından anlaşıldığı üzere Neoklasik üslupta dönemin anlayışına uygun olarak inşa edilen Surp Nersesyan Mektebi, tek bir bloktan ibaret iki kanat halinde düzenlenmiş simetrik bir şemaya sahip olup her bir kare, plan konturu ile sınırlandırılarak, kendi içerisinde dikdörtgen bölmeleri barındırmakta, biri subasman katı olmak üzere toplamda üç kattan oluşmaktadır.

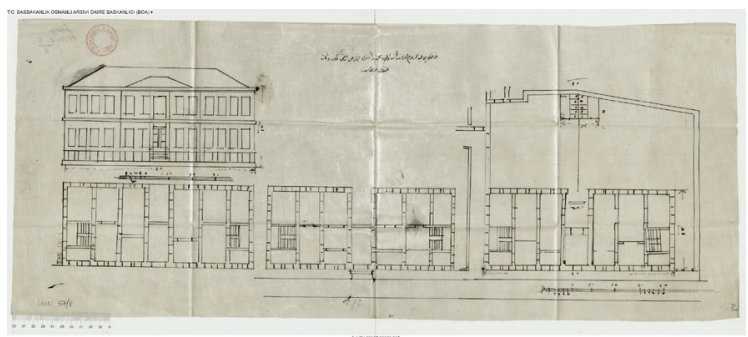

F. 2: Hasköy Abdüsselâm Mahallesi'ndeki eski okulun yerine yapılacak olan Ermeni Kız-Erkek Okulu Projesi (BOA.İ.AZN.57.8.2)

Giriş, orta aks üzerinden olmakla birlikte, yan uçlara yerleştirilen T planlı ortak alanlardaki merdiven kovalarından alt ve üst katlara çıkış sağlanmıştır. T şeklindeki ortak alanların iki yanında ise mekânın hacminden ötürü sınıf olamayacağı; fakat diğer işlevsel mekânlar için kullanıldığı düşünülen köşe odaları bulunmaktadır. Köşe odalarının üzerinde ise aynı boyutlarda yan yana üç dikdörtgen oda görülmektedir. Aynı simetrik sıralama diğer tarafta da tekrar edilmiştir.

Üst kata çıkıldığında giriş katındaki düzenin tekrar etmediği dikkat çekmektedir. Bu kattaki merdiven kovalarında birer dikdörtgen sofa alanı ile karşılaşılmakta, bunun sol tarafında ise küçük bir oda bulunmaktadır. Ancak planın şematikliğinden kaynaklı odalara giriş açıklıkları belirtilmemekle birlikte üç büyük, bir adet de orta büyüklükte oda mevcut olup aynı sıralama

33 BOA.İ.AZN.57.8.2.1.

34 BOA.İ.AZN.57.8.1.1 (Tarih: R. 8 Temmuz 1320/M. 21 Temmuz 1904).

35 BOA.İ.AZN.57.8.4.1 (Tarih: R. 4 Ağustos 1320/M. 17 Ağustos 1904).

36 BOA.MF.MKT.805.64.1.1 (Tarih: R. 15 Ağustos 1320/M. 28 Ağustos 1904). 
diğer tarafta da takip edilmiştir. Her ne kadar bir koridorun varlığına göre mekânların dağılımı beklense de planın hiçbir katında böyle bir alana yer verilmemektedir.

Subasman katı planından merdivenin tüm yapıyı dolandığı anlaşılmaktadır. Bu katın da -binanın diğer katları ile bir tekrar teşkil etmese de- yine kendi içerisinde simetrik olduğu dikkati çekmektedir. Plandan ve okulun arka cephesine ait fotoğrafından da anlaşıldığı üzere mimarî düzenlemeyi ikiye bölen orta aksının arka taraftan içe çekildiği ve bu çekilmenin subasman katında da var olduğu görülmektedir (F.3). Subasman katındaki içe çekilme sebebiyle muhtemelen bir kapı ile bahçe kotuna çıkılmaktadır. Surp Istepanos Kilisesi'nin yakınına inşa edilen Surp Nersesyan Mektebi'nin müstakil bir bahçesi olduğu plandan anlaşılmaktadır. Yine plandan ve fotoğraftan anlaşılabildiği üzere okulun bahçesi binanın arka tarafına denk düşmekte, sınıf olarak kullanılan mekânların ise bu cephede yer aldığı anlaşılabilmektedir. Bahçe planında bir yapının daha varlığı görülse de tam olarak hangi amaçla kullanıldığı tanımlanamamış olup, okulun müştemilatı ya da odunluğu olabileceği düşünülmektedir.

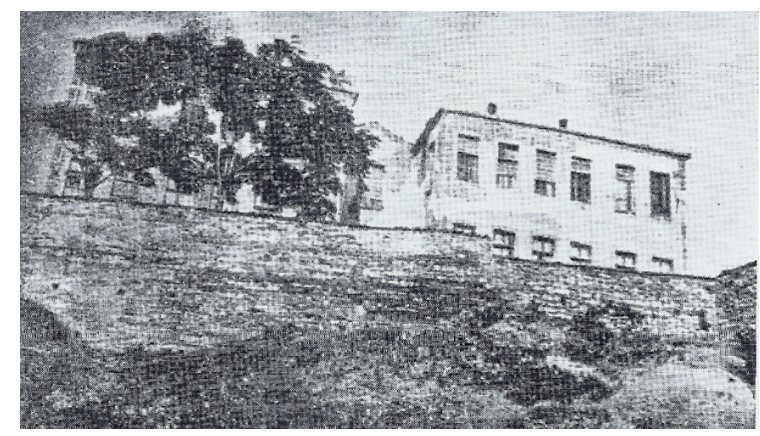

F. 3: Hasköy'de inşa edilen Surp Nersesyan Ermeni Okulu (Varjabedyan, 1931, s. 63.)

Okulun arka cephesine ait fotoğrafından binanın yığma tekniğinde taş üzeri sıva kaplanmış olduğu, köşelerin kesme blok taş ile strüktürel olarak güçlendirildiği görülür. Kırma çatıya sahip yapının ön cephesinin gösterildiği planın orta bölümde var olan çizgilerin plastr oldukları düşünülmektedir. Giriş kısmının daha kalın olarak vurgulandığı yapının ön cephesinde bahçe katından üst kata kadar düşey aks üzerinde sürekliliğini koruyan plastırlar ile birlikte, geniş açıklıklı, yüksek ve sık düzende dikdörtgen sade pencereler, fotoğraftan anlaşıldığı üzere arka cephede de tekrarlanmaktadır. Her ne kadar plandan yan cephelerde kaçar pencere olduğu anlaşılamasa da eldeki verilerden iç mekânın hayli aydınlık olduğu, tavan kotlarının da yüksek tutulduğu anlaşılabilmektedir.

Sonuç olarak yapının arşivden çıkan plan bir rölöve olmadığı için uygulama ile proje arasında fark olup olmadığı tespit edilememektedir. Yine aynı sebepten ötürü iç mekândaki odaların form ve fonksiyonunun nasıl bir anlayış ile yapıldığı; konferans salonu, müzik odası, laboratuvar vs. gibi modern eğitimin göstergesi olan mekân tiplerini barındırıp barındırmadığı anlaşılamamaktadır. 
I. Dünya Savaşı'nda Surp Nerseyan Mektebi'nin askerî garnizon olarak kullanılması sebebiyle açıkta kalan talebeleri, semtteki Protestan ibadethanesinin alt katında eğitim gören kırk Protestan öğrenciye katılmak durumunda kalmışlardı. Şartlar gereği birleşen bu iki okulun idaresi; Amerikan Misyoner Teşkilat1 ${ }^{37}$ [American Board of Commissioners For Foreign Missions (ABCFM)] adına Osmanlı'da faaliyet gösteren misyonerlerden bir temsilci, Protestan Cemaati'ni temsilen Pastör Hovhannes Ağasyan ve Surp Istepanos Kilisesi Yönetim Kurulu'nu üyelerinden Ardaşes Sarkisyan'dan oluşan üç kişilik komiteye teslim edilmişti. Birleşen bu okulda eğitim, Pastör Penyamin Bedrosyan'ın idaresi ve misyonerlerin desteği ile 1922 yılına kadar sürmüştü. Fakat Mütareke Dönemi’nde gelen göçmenlerle beraber sayıları üç yüze ulaşan talebelerin okula sığamamaları sebebiyle eğitim, yeniden Surp Nersesyan Mektebi'ne nakledilmişti. ${ }^{38}$

Maddî sıkıntıların baş gösterdiği bu dönemde "Cemaat Yardım Komisyonu” [Azkayin Khınamadarutyun], ihtiyacı olan talebelere yardımda bulunarak öğle yemeği vermeye başlasa da bir süre sonra sadece bir çocuk için ayda elli kuruş ödeyebilecek duruma gelmişti. Komisyonun gelirlerinin daralmasıyla Patrikhane yardımları ve Maârif'ten gelen destekle varlığını sürdürmeye çalışan okula, Surp Istepanos Kilisesi "Fakirlere Yardım Kolu” da 1929'a değin iki buçuk yıl boyunca yardımcı olmuştu. 1930'lara gelindiğinde yüz kadar öğrenciye sahip okul, yılda 2670 liralık bir bütçe ile idare edilmekte, bu meblağın 1000 lirasını "Kilise Yönetim Kurulu” ödemekteydi. ${ }^{39}$

Ermeni çocuklara yatılı eğitim imkânı sağlayan Şişli'deki Karagözyan ve Hasköy’deki Kalfayan'ın yoğunluğunu azaltmak amacıyla 1964 yılında yatılı sisteme geçen ${ }^{40}$ okul için 1969'da Boğaz geçişi ve bağlantı yollarının inşası sebebiyle istimlak kararı çıkmıştı. Kararın 1971'de uygulanmasıyla öğrenciler, Üsküdar'daki Tıbrevank Okulu'nun yakınlarındaki bir binaya aktarılsa da Surp Nersesyan Mektebi daha fazla varlığını devam ettiremeyerek 1980'li yıllarda eğitim hayatına son vermek durumunda kalmıştı. ${ }^{41}$

\section{Kalfayan Kız Yetimhanesi}

Kalfayan Kız Yetimhanesi, Ermenilerin Hasköy’deki sosyal yardımlaşma kurumlarının başında gelen, sadece himaye değil, kimsesiz ve muhtaç kız çocuklarına meslek eğitiminin yanında modern bir eğitimin de verildiği önemli kurumlardan biriydi.

37 Amerikan Misyoner Teşkilatı'nın genel tarihi için bkz. William E. Strong, The Story of the American Board: An Account of the First Hundred Years of the American Board of Commissioners for Foreign Missions, Boston, Pilgrim Press, 1910.

38 Varjabedyan, a.g.e., s.67.

39 Varjabedyan, a.g.e., s.67-69.

40 Anonim, Jamanak, 21 Temmuz 1964, s. 4.

41 Talin Sarraf, "Bir Zamanlar Okuldu: Haliç Köprüsüne Kurban Gitti”, Agos, İstanbul, 10 Ocak 1997, s.3. 
Kurucusu Kartallı Sırpuhi Nışan Kalfayan² ${ }^{42}$ (1822-1889) (F.4), semtin yetim kızlarına oya ve dival işlemeyi öğreterek hem onlara bir meslek edindirmekte hem de evinin geçimini sağlamaktaydı. Başlarda el işlerinin satışlarından elde edilen gelir ve şahsî birikimi ile idame etse de bir süre sonra sıkıntı çekmeye başlayan Rahibe Sırpuhi, Hasköy’un ruhanilerine ve mahalle konseyine başvurarak yardım talebinde bulunmuştu. Onun bu çağrısı üzerine dönemin Surp Istepannos Kilisesi Vaizi Episkopos Nerses Varjabedyan ${ }^{43}$ (1837-1884), yetim kız çocuklarını koruyacak bir Rahibeler Birliği'nin [Mayrabedagan Miapanutyun] oluşturulabileceğine dair önerisini, hazırladığ 1 dört ana maddeden oluşan "Rahibeler Birliği Tüzüğü" ile birlikte, 25 Ağustos 1866'da Patrik Boğos II. Taktakyan'a (1863-1869/d. 1794-ö. 1872) sunarak, bağ1Ş toplama izni talep etmişti. Patrik'in Varjabedyan'ın talebini 3 Eylül 1866'da tasdiklemesinin ardından Rahibe Sırpuhi, Hasköy-Sandalcı Sokak'ta bulunan Posta Nazırı dayısı Krikor Ağaton'a (1825-1868) ait evi 21 Kasım'da Ermeni kız yetimhanesi olarak kullanıma açmış, on beş gün içerisinde de dördü Halıcıoğlu-Çıksalın Mahallesi’ndeki bir ahırdan, yedisi aynı mahalledeki Surp Istepanos Kilisesi civarından, geri kalanı ise şehrin çeşitli semtlerinden, iki ila on yaşları arasında kimsesiz on yedi öksüz kızı himayesine almıştı. ${ }^{44}$

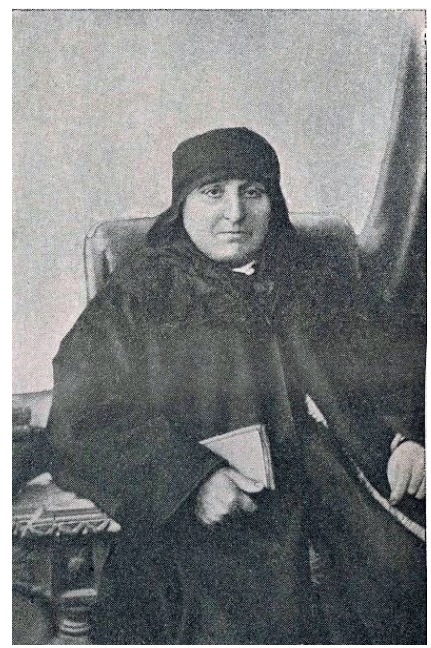

F. 4: Kartallı Sırpuhi Nışan Kalfayan (1822-1889)

(Anonim, Keğuni, 1901, s. 6.)

42 Elâzı̆̆-Palulu bir ailenin kızı olan Sırpuhi, 12 yaşında babasını kaybetmesinin ardından dayısı Krikor Ağaton'un Hasköy'deki konutuna yerleşmiş, 18 yaşındayken de rahibe olmasının ardından ömrünü öksüz Ermeni kız çocuklarına vakfetmişti (Anonim, Vatsunamyag Kalfayan Ağçıgants Vorpanotsi, Hasküğ (1886-1926) [Kalfayan Kız Yetimhanesi'nin 60. Yıldönümü, Hasköy], H. M. Setyan Matbaası, İstanbul, 1926, s.3-4).

43 Surp Nersesyan Mektebi mezunu Nerses Varjabedyan, 1874-1884 tarihleri arasında II. Nerses adiyla Ermeni Patrikliği görevinde bulunmuştur.

44 Hagop Çınar, Berç Erziyan, Harüramya Hişadagaran Kalfayan Dan, 1866-1966 [Kalfayan Evi'nin 100. Y11 Anı Kitabı], A. H. Matbaası, İstanbul, 1966, s.9, 12-16, 23. 
Giderek daha fazla kimsesizi himayesi altına alınca giderleri çoğalan yetimhanenin masraflarını karşılayabilmek için Rahibe Sırpuhi, 1870 yılında Sultan Abdülaziz'e (sal. 1861-1876) huzura çıkmak istediğine dair bir mektup göndermişti. Arzusu kabul edilen rahibe, yetimleriyle birlikte 2 Mayıs'ta Kâğıthane'de ağırlanmış ve padişah tarafından idaresi altındaki kuruma 50 altın, elbiselik kumaşlar ile günlük 7,5 okka et ve 15 okka ekmek tahsis edilmişti. ${ }^{45}$

Her ne kadar yetimhane, kızların barınma ve yiyecek gibi ihtiyaçlarını karşılasa da o döneme değin eğitimleri konusunda bir girişimde bulunamamıştı. Kurum, 1871'de malî sıkıntılarının hafiflemesiyle, Armenolog ve tarihçi Reteos Tateosyan'ın temel eğitim derslerini vermek için gelişiyle, sadece meslek öğreten değil aynı zamanda eğitimlerini de sağlayan bir yapı halini almıştı. ${ }^{46}$

Kalfayan'ın binası, zamanla artan yetim sayısı nedeniyle yetersiz gelmeye başlayınca, vaktiyle Taniel Dakes Amira'nın ${ }^{47}$ mülkü olan Hasköy-Abdülsselâm Mahallesi Türbe Sokak'taki on iki oda, bir salon, bir de hamamdan teşekkül bahçeli ahşap köşk satın alınmıştı. Gayrimenkul, açık arttırma usûlü ile satışa çıkarılmış, Rahibe Sırpuhi’nin 950 altınlık teklifinin üzerine çıkan olamamıştı. Kurum, tadilat ile birlikte toplam 1200 altına mâl olan yeni binasına, 1 Mart $1877^{\prime}$ de yirmi üç yetim ile birlikte geçmişti. ${ }^{48}$

Ömrünün son yıllarına kadar yetimhaneye gelir sağlayabilmek için bağış toplamaya devam eden Rahibe Sırpuhi, yetimlerin işlediği oya örtüyü Sultan II. Abdülhamid'e (sal. 1876-1909) 1883 yılında hediye olarak göndermiş, buna karşılık padişah da yetimhaneye 300 altın ihsan etmişti. Bu bağışla yetimhaneye akar sağlaması maksadıyla Silahtarağa' da bir dükkân satın alınmıştı. ${ }^{49}$

45 Bu bağış, II. Meşrutiyet dönemindeki iki yıllık ara hariç, 1923’e kadar devam etmişti (Çınar, Erziyan, a.g.e., s.19-20).

46 Çınar, Erziyan, a.g.e., s.20.

47 Yetimhanede bulunan çeşmedeki 1225 (M. 1776) tarihli kayıttan, bahsi geçen binanın daha önce "Ekmekçi" lakabıyla bilinen Eğinli fırıncı Dakes Amira’ya ait olduğu anlaşılmaktadır. Ekmekçi Dakes, III. Selim'in kaptan paşalarından Hüseyin Paşa'ya görevinden men edildiği on yıl boyunca maddî ve manevî yardımda bulunmuştu. Paşa da görevine dönünce Dakes’i hem hususî sarrafı olarak atamış hem de bahsi geçen evi ve arsasını ona ferağ etmişti (Varjabedyan, a.g.e., s.87-88; Çınar, Erziyan, a.g.e., s.21).

48 Çınar, Erziyan, a.g.e., s.20, 174.

49 Yıllar içerisinde yetimhaneye ait mülkler bağış, satın alım ve miras yoluyla çoğalmıştı: Kartal'daki Sağir Yol'da Nigoğos Efendi Hovasepyan'ın inşa ettiği beş odalı tek katlı taş bir bina, Galata'da Mumhane Sokak No: 1'deki daire, Eminönü Büyük Valide Han'daki No: 65'teki dükkân, Balat’ta bir evin kira geliri, Kalcılar Han'daki 8, 11 ve 40 numaralı odalar, Kapalı Çarşı No: 26'daki oda, Taksim Feridiye Sokak No: 33’teki ev, Taksim Çaylak Sokak No: 14'teki ev, Eminönü Fincancılar Sokak'taki Yusufyan Hanı'nın 1/10 hissesi, Şişli Hanımefendi Sokak’taki No: 41'deki apartmanın 1/2 hissesi, Simon Kayseriliyan tarafından bağışlanan Üsküdar Altunizade'deki yazlık, Pera Sakızağacı Mahallesi No: 18'deki ev, Harbiye Caddesi'ndeki bir apartmanın 1/2 hissesi, Üsküdar İcadiye Çamlıca Caddesi No: 31 'deki ev, Üsküdar Bağlarbaşı Caddesi No: 373 ’teki ev vb. (Çınar, Erziyan, a.g.e., s.22). 
Sirpuhi Kalfayan, yetimhaneyi yirmi dört yıl yönettikten sonra 4 Temmuz 1889 tarihinde altmış yedi yaşında vefat etmiş; cenazesi Surp Istepanos Kilisesi'nden kaldırılarak, naaşı yetimhanenin bahçesinde bulunan Surp Asdvadzadzin [Meryem Ana] Şapeli'ne ${ }^{50}$ gömülmüştü. ${ }^{51}$

Rahibe Sırpuhi'nin ardından Rahibe Yeranuhi Hovhannesyan (görev süresi 1899-1902), yetimlerin bakımını üstlenmişti. Kurumda yetişen Yeranuhi, başlarda başarılı faaliyetlerde bulunmuşsa da sonrasında yetimhaneyi madden ve manen zarara uğratması üzerine görevinden el çektirilmişti. ${ }^{52}$ Patrik Ormanyan'ın görev süresinin ilk yıllarında durumu hayli kötüleşen kurumun bağışları durmuş, eğitim işlerini üstlenen Reteos Tateosyan istifa etmiş, yetimlerin sayısı azalmış, dahili disiplini bozulmuştu. Eğitim ve bakım düzeyi düşen yetimhaneye özel ihtimam gösteren Patrik Ormanyan duruma el koyarak, Dr. Istepan Paşa Aslanyan'dan kurumun sorumluluğunu üstlenmesini istemiş, ayrıca yetimlerle ilgilenilmesi için 10 Mayıs 1902'de dönemin Ermeni entelektüel çevresinin önemli feminist ve aktivist yazarlarından Sırpuhi Düsap'ın (1841-1901) da bulunduğu “Kadınlar Kurulu”nu [Dignants Khnamagalutyun] oluşturmuştu. ${ }^{53}$ Aslanyan'ın yetimhaneyi bir yıl kadar yönettikten sonra görevi bırakmasıyla Patrik, bu defa Patrikhane'nin iki kalem müdürünü; Partoğ Telpan ile Garabed Haçaduryan'1 yetimhanenin ıslahı ile görevlendirmiş, onların çalışmaları sonucunda kurumun maddî ve manevî durumu eski günlerine kavuşmuştu. ${ }^{54}$

Yeranuhi'nin ardından, Patrik Ormanyan'ın teklifiyle Surp Pırgiç Ermeni Hastanesi'nin rahibesi Rahibe Kristine Papazyan ${ }^{55}$ (görev süresi 13 Ekim 1902-1919) vazife başına getirilmiş, kendisine yardımcı olarak da Ağavni ve Maryam Köseyan kız kardeşler görevlendirilmişti. ${ }^{56}$

1904 'te uzun zamandır onarım ihtiyacı olan yetimhane binası ve şapel, halktan 1200 altın bağış toplanmasının ardından başkan Yeğya Şahbaz, yardımcılar Dikran Parağamyan, ${ }^{57}$ Mimar Krikor Melidosyan ve Yetvart Karagözyan'dan oluşan “İnşa Heyeti”nin [Şinutyan Hantznakhump] denetiminde, Mimar Istepan Hamamcıyan tarafından tadil edilmişti. ${ }^{58}$ Elimizde bu dönemde kullanılan binanın plan ya da fotoğrafı henüz bulunmamakla birlikte, binaya ikinci katın çıkıldığı, misafirhanenin yanındaki iki odanın birleştirilmesiyle geniş bir yemekhanenin

50 Kalfayan Kız Yetimhanesi içerisine inşa edilen küçük Surp Asdvadzadzin Şapeli, Rahibe Sırpuhi'nin ölümüne yakın, Patrik Khoren Aşıkyan'a (1888-1894/d. 1842-ö. 1899) son arzusunun yetimhanenin bahçesine yapılacak bir şapele defnedilmek olduğunu söylemesi üzerine beş gün içerisine ahşaptan inşa edilmişti. Uzun yıllar yetimhanedeki kızların ve diğer görevlilerin dinî ibadetlerini gerçekleştirdikleri bir mekân olarak kullanılan bu şapel, 1971 yılındaki istimlâk sırasında yıkılmıştır.

51 Varjabedyan, a.g.e., s.76.

52 Görevinden el çektirilmesinden kısa süre sonra Rahibe Yeranuhi, 22 Kasım 1902 günü felç geçirerek vefat etmiş ve Hasköy'deki Ermeni mezarlığına gömülmüştür.

53 Anonim, Vatsunamyag Kalfayan Ağçıgants Vorpanotsi, Hasküğ (1886-1926) [Kalfayan Kız Yetimhanesi'nin 60. Y1ldönümü, Hasköy], s.15.

54 Hovnan Palakaşyan, "Hişadagneres Badarig Mı" [Anılarımdan Küçük Bir Parça], Jamanak, İstanbul, 15 Eylül 1926, s.3.

552 Aralık 1902 tarihinde Patrik Ormanyan bir genelge ile Kristine Papazyan'ı başrahibe takdis etmişti.

56 Çınar, Erziyan, a.g.e., s.35-36.

57 Hasköy'ün eğitim kurumlarına yüklü bağışlar yapanların başında Parağamyan Efendilerin geldiği anlaşılmaktadır.

58 Anonim, Vatsunamyag Kalfayan Ağçıgants Vorpanotsi, Hasküğ (1886-1926) [Kalfayan Kız Yetimhanesi'nin 60. Y1ldönümü, Hasköy], s.19. 
oluşturulduğu, hamam ve mutfağın onarıldığı, merkezî 1sıtma ve su arıtma sistemlerinin yapıldığı kaynaklardan yazan bilgiler arasındadır.

Patrik Mağakya Ormanyan otobiyografisinde bu konuya değinmektedir:

“(...) Hasköy'de kurulmuş olan Kalfayan Yetimhanesi’nin de onarıma ihtiyacı vardı. Kadınlar Kurulu'nun gayreti ile boya ve dam onarımı için alınan basit izinle, fabrikatör Yeğya Şahbazyan'ın becerisiyle bina, sadece içerden değil dışardan da yenilenmiş oldu. Ayrıca kutsanmasını da 4 Aralık 1904 tarihinde bizzat kendim yaptım. Kalfayan Yetimhanesi'ni daha da genişletmek ve Surp Pırgiç Yetimhanesi'nin tamamlanmasını organize etme arzum vardı. Bu amaçla da Cezayirliyanlar'ın terk etmiş olduğu ve Kalfayan'ın duvarına bitişik, devlet tarafından borcu karşılığında el konulmuş olan köşkü almaya çalıştım. Sonunda saraydan 19 Mayıs 1908 tarihli iradeyi alabildim. İki binayı bölen duvardan geçişi 10 Temmuz'da bizzat açtım. Ancak üç hafta geçmeden patriklikten istifa ettim." ${ }^{59}$

Patrik Mağakya Ormanyan'ın bahsettiği belge ve bu belgenin devamında verilen kararlara Cumhurbaşkanlığı Osmanlı Arşivi’nde rastlanılmıştır. Mart 1910 tarihli belgeye göre, Mıgırdıç Cezyirliyan'ın ölümü sonrası, vârisi olmadığından boşta kalan arsanın yetimhaneye bedelsiz ${ }^{60}$ olarak devri konusunda Mayıs 1908 tarihli bir padişah emri çıkmıştı ${ }^{61}$ Çıkan iradeden sonra, ${ }^{62}$ söz konusu arsa hakkında bir araştırma yapılmış ve neticeleri de Evkaf Nezâreti'nin bu yazısından yaklaşık bir ay sonra Şurâ-yı Devlet’te görüşülüp karara bağlanmıştı. Belge metnine göre; 12 Nisan 1910 tarihli bu kararda vefat etmiş olan Mıgırdıç Cezyirliyan'ın vârisi olmadığı için boşta kalan arsasının belli bir bedel karşılığında yetimhaneye devri konusu görüşülmüştü. ${ }^{63}$ Şurâ-y1 Devlet' in buradaki incelemesinden, Hasköy Abdüsselâm Mahallesi'nin II. Bayezid'in vakfı olduğu, söz konusu arsanın Cezayirlioğlu Sokağı'nda 14 numarada bulunduğu görülmüştü. Bu arsanın toplam yedi hissesi vardı. Yedi hisseden üçü Nazlı binti [kızı] Hovhannes'e, biri Vartan oğlu Hovhannes'e ve kalan üç hisse de Kevork Bey’in zevcesi Ebru binti Arakes'in üzerine kayıtlıydı. Bu hissedarlardan üç hissenin sahibesi olan Nazlı öldüğünde geride Mıgırdıç ve Marice isimlerinde iki evladı kalmıştı. Mıgırdıç'ın çocuğu olmayıp, Marice'in ise beş evladı vardı. Bu beş evladından Garabed'in de çocuksuz olarak ölmesiyle, söz konusu arsanın toplam 70 hissesinden, vârissiz 18 hissesi II. Bayezid Vakfı'na

59 Mağakya Ormanyan, Kho yev Khosk [Tefekkür ve Söz], Hagopyan Matbaası, Yerusalem, 1929, s.248.

60 “(...) mütevefâ cezâyirli oğlı mıgırdıçdan mahlûl olub Hasköyde inâs eytâmhânesine bilâ-bedel tefvizi (...)" ifadesi ile bedelsiz olarak arsanın yetimhaneye Padişah II. Abdülhamid tarafından verildiği bilgisi için bkz. BOA.BEO.4081.306069.1.1 (Tarih: H. 25 N 1330/M. 7 Eylül 1912).

61 "Cezâyirli oğlı Mıgırdıçdan mahlûl olan menzil arsasının Hasköyde ermeni inâs eytâmhânesine tefvizi hakkında mabeyn baş kitabetinden 20 Mayıs (1)324 [2 Haziran 1908] tarihli tezkeresiyle tebliğ olnan irade-i seniyye üzerine icrâ kılınan tahkikâtda (...)”. BOA.ŞD.195.16 (Tarih: H. 7 Ra 1328/M. 19 Mart 1910).

62 İradenin çıkış tarihi ile arsa üzerine yeni iktidar tarafından araştırma yapılmaya başlandığı tarihi dikkate alınırsa, söz konusu arazinin yetimhaneye devredilmesi için onay veren Sultan II. Abdülhamid, daha sonra İttihat ve Terakki Partisi tarafından tahttan indirilince, yeni hükümet padişahın son zamanlarda verdiği kararları yeniden gözden geçirmek istemiş olmalıdır. Çünkü arsa devrinin iptali meselesi de yeni hükümetin irade-i seniyye üzerine yaptı̆̆ 1 son düzenlemelerden sonra çıkmıştır.

63 "Müteveffa Cezayirli oğlu mıgırdıçdan mahlûl olân menzil arsasının hasköyde ermeni inâs eytâmhânesi nâmına tefvizi” BOA.BEO.3734.280039.2.1 (Tarih: H. 1 R 1328/M. 12 Nisan 1910). 
devredilmişti. 70 hissenin 160,600 kuruşluk kıymetinden, boş kalan 18 hisseye 41,300 kuruş bedel isabet etmiş, Patrikhane de boş kalan bu hisselerin bir kısmı üzerine yetimhaneyi inşa ederek, arsanın tapusunu (sened-i hâkânî) talep etmişti. "(...) hâkân-1 mahlu“64 tarafindan irâde-i seniyye ile tefviz olınan mahlûlâtın (...)" ifadelerine göre Sultan II. Abdülhamid, tahttan hal' edilmeden önce söz konusu arsanın, Partik Mağakya Ormanyan'ın bahsettiği gibi, yetimhane üzerine devri için izin vermişti; ancak daha sonra İttihat ve Terakki yönetimi tarafından bu hüküm geri alınmıştı. Belgedeki verilere göre; aynı zamanda mesken arsası olan bu yerin usûlen hissedarlarına devri gerekmekteydi. Patrikhane'nin beyanatına göre buranın bir kısmına yetimhane inşa edildiği için de arsa "mesken” vasfını kaybetmişti. Vârissiz kaldığı ve arsanın bazı hisselerinin vakfa devri yapıldığı için vakıf arsasının da bedelsiz olarak yetimhaneye devri mümkün görülmemekteydi. Patrikhane ise yetimhanenin inşa edildiği arsaya düşen bedelin, tarafınca karşılanmasının mümkün olmadığını belirtmişti. Ayrıca, yetimhane hissesine düşen miktar üzerinden bir indirim ya da azaltma da söz konusu değildi. Bu nedenle yetimhane hissesi bedeli olan 41,300 kuruşun devlet tarafindan tahsil edilmesi gerekmekteydi. Vakıf mallarının korunması kanunları çerçevesinde, vefat eden Cezayirli Mıgırdiç’ten boşalan ve üzerine yetimhane yapılan menzil arsasının, bedelsiz olarak verilmesi mümkün olmadığı için arazi bedeli olan 41,300 kuruşun Partikhane tarafından vakfa ödenmesine, arazinin bu şekilde yetimhane adına devrinin yapılmasının Evkâf Nezâreti'ne tebliğ edilmesine karar verilmiş, ${ }^{65}$ karar birkaç gün sonra makama iletilmişti. ${ }^{66}$

Arsa meselesinin bazı kurumlar arasındaki yazışma ve incelemeler çerçevesinde bir süre daha çözülemediği anlaşılmaktadır. Nitekim bu incelemeler neticesinde Mâliye Nezâreti Şubat 1913 tarihli bir yazısını, Meclis-i Vükelâ’ya görüşülmek üzere göndermişti. Meclis-i Vükelâ'nın yazısına göre Patrikhane, önceden bedelsiz olarak yetimhaneye devredilen arazinin daha sonra geri alınmasına yönelik kararın bu gibi hayır kurumlarını kapsamaması gerektiğini, bünyesindeki seksen yetimi barındırma noktasında artık yetersiz kalan mekânından ötürü söz konusu arsaya şiddetle ihtiyacı olduğunu, Patrikliğin arsa için biçilen bedeli karşılamasının zorluğunu belirtmiş, 41,300 kuruşluk arsa bedelinin Mâliye Hazinesi tarafından karşılanmasını istemişti. ${ }^{67}$

64 Hâkân-1 mahlu': Hal' edilmiş, tahttan indirilmiş.

65 BOA.BEO.3734.280039.2.1 (Tarih: H. 1 R 1328/M. 12 Nisan 1910).

66 BOA.BEO.3734.280039.1.1 (Tarih: H. 5 R 1328/M. 16 Nisan 1910).

67 “(...) bilâ bedel tefviz olunan mahlûl emlâkin istirdâdına dâir olan kararın müessesât-ı hayriyye ve "umumiyyeye şâmil olmayacağı ve derûnında i'âşe ve terbiye idilen seksen nefer eytâmı isti'âya kâfi bulunmayan eytâmhânenin menzil-i mezkûre şediden muhtâc ve bedel i'atâsına gayr-i müktedir bulundığı beyanıyla bedelinin hazine-i mâliyece (...)". Belge sonucunda konu hakkındaki neticenin ne olduğu bilinmemektedir. Ayrıca belgenin devamındaki birkaç satırlık veri, arazi meselesi haricinde olup, yetimhaneye yapılan gıda yardımlarına yöneliktir. 1908 yılında yeni hükümetin, yetimhaneye o tarihe kadar yapılmakta olan yardımları kestiği bilinse de bu belgeden bahsi geçen yardımların bir süre sonra tekrar yıllık olarak verilmeye devam ettiği görülmektedir: “(...) eytâmhânenin nân-1 'aziz mu'inâtı içün hazinece senevî on sekiz bin kuruş tahsisât virilmek suretiyle ibrâz-1 mu'âvenet idilmekde oldığı (...)" ifadelerinden, yetimhaneye ekmek ihtiyacı (nân-1 aziz muinâtı) için hazine tarafından yıllık 18,000 kuruş bütçe ayrılarak, yardım yapılmaya devam edildiği anlaşılmaktadır. 
1908 yılında II. Meşrutiyet döneminden başlayıp İttihat ve Terakki'nin idareyi ele almasıyla birlikte, yetimhanenin gıda ihtiyaçları için II. Abdülhamid'in şahsî hazinesinden her yıl yapılan yardımların kesildiği, o tarihlerde bizzat Ermeni Patriği'nin Sadâret'e gönderdiği yazısından anlaşılmaktadır. 31 Ekim 1908 tarihli yazısında Patrik Yeğişe I. Turyan ${ }^{68}$ (1909-1910/d. 1860-ö. 1930), yetimhaneye padişahın şahsî hazinesinden verilen günlük 15 okka ekmek ve 7,5 okka et yardımının kesildiği bilgisinin Hazine-i Hassa memuru tarafından kendilerine bildirildiğini, bünyesinde yetmişten fazla öksüz kız çocuğunun bakılıp eğitildiği bu hayır kurumunun yardımlarının kesilmesinin buranın idaresini imkânsız hale getireceğini ve kız çocuklarının sefil bir şekilde meydanda kalacaklarından duyduğu endişeyi dile getirmekte, son olarak da günlük et ve ekmek yardımının eskisi gibi verilmeye devam edilmesi hususunda Sadâret'ten yardım istemekteydi. ${ }^{69}$ Patrik Yeğişe'nin bu yazısı üzerine söz konusu talebi ilgili kurumlarda değerlendirilmiş ve II. Meşrutiyet'le birlikte, padişahın şahsî tüm mal varlığının/ gelirlerinin Mâliye Hazinesi'ne devredilmesi sebebiyle reddedildiği Hazine-i Hassa Nazırı imzalı belgeden anlaşılmaktadır. ${ }^{70}$

1910'lu yıllara gelindiğinde yetimhaneye bitişik bir derslik açılması planlanmıştı. Bu amaçla Mısır Kapı Kethüdası Apraham Paşa Yeramyan, 2500 arşınlık arsasını kuruma bağışlamıştı. ${ }^{71}$ İnşa için bağış ve vasiyet yoluyla toplanan 2000 lira ile yetimhanenin 2500 liralık birikimi bu amaca tahsis edilse de patlak veren I. Dünya Savaşı projenin aksamasına sebep olmuş ve biriken yekûnun daha elzem ihtiyaçlar için kullanılmasına karar verilmişti. ${ }^{72}$ Savaş döneminde kurumun en büyük gelir kaynağı olan bağışlar kesilip, malzemelerin temin edilememesinden ötürü işleme atölyelerinin de üretimi durunca maddî durum iyice kötüleşmişti. Bu sebeple yetimhanede bulunan altmış yetimden onu durumu uygun olan ailelerin yanına gönderilmiş, ikisi evlatlık verilmiş, sekizi ise öğretmenlik gibi görevlerde çalışmak için kurumdan ayrılmıştı. Yine de 1915 Tehcir Kanunu sonrasında yetim kalarak İstanbul'a gelen Ermeni kız çocuklarını kabul eden yetimhane, onların bakım ve eğitimlerini üstlenmişti. ${ }^{73} \mathrm{Bu}$ dönemde fiziksel mekânının yetersizliğinden ziyade yetimhanenin en büyük sıkıntısı, erzak teminiydi. Her ne kadar mülke ait araziye ekim yapılıp, hayvanlardan elde edilen gıdalar ile idare edilmeye çalışılsa da mevcut

68 Patrik mührü üzerinde "Patrik-i Millet-i Ermeniyân Kaimmakâm-1 Serpiskopos Yeğișe" yazmaktadır.

69 "Hasköy'de kâin inâs eytâmhânesine hazîne-i hassâ-i şâhâneden i'atâ buyrılagelen yevmî 15 kıyye nân-1 'azîz ve yedi buçuk kıyye lahm mu'înâtın kat' idilmiş oldığı, hazîne-i müşârun ileyhâ mu'înât me'mûrı tarafından bildirilmişdir (...)"/ "Eytâmhâne derûnında terbiye ve i'âşe idilmekde olân yetmiş neferi mütecâviz öksüz ve fakir kız çocukların idaresince zâten müşkilât çekilmekde iken bir de mu'înât kat' idilecek olsa müessesât-1 hayriyye-i mezkûrenin devâm-1 idâresi gayr-i kâbil bir hâle dûçâr olacağından ve ol mikdâr fakir kız çocuklar (...)”/ “(...) mu'înât-1 mezkûrenin kemâ fi's-sâbık devâm-1 i'atâsı zımnında (...)”. BOA.BEO.3425.256828.2.1 (Tarih: R. 18 Teşrinievvel 1324/M. 31 Ekim 1908).

70 “(...) bu gibi hayrât karşulığı olân emlâk-1 hümâyûn vâridâtından kısm-1 küllîsinin hazîne-i mâliyeye terk idilmiş olmasına (...)”. BOA.BEO.3425.256828.3.1 (Tarih: R. 9 Teşrinisâni 1324/M. 22 Kasım 1908).

71 Yeramyan Paşa'nın bağışladığı arsanın yeri bilinmemektedir. Bu sebeple paşanın arsayı yetimhaneye ya satışından gelir etmesi ya da akar sağlaması için bağışladığı tahmin edilmektedir.

72 Varjabedyan, a.g.e., s.83.

73 Hımayak Şişmanyan'ın eğitmen olduğu 1915-1919 döneminde on iki mezun veren yetimhanenin toplam öğrenci sayısı doksanı bulmaktaydı (Çınar, Erziyan, a.g.e., s.40). 
öğrenci sayısı kapasitenin üzerinde olduğu için gereksinimler karşılanamamakta; bazı ihtiyaçlar karneyle alınan gıdalardan arttırılıp takas usûlüyle giderilmekteydi.

Baş Rahibe Kristine Papazyan imzasıyla, Kalfayan Kız Yetimhanesi'nde barınan kız çocuklarına yapılan iaşelerin arttırılması hakkında hükümete yazılan dilekçe ${ }^{74}$ üzerine Nazır Talat Paşa'nın İaşe-i Umumiye Müdürü İsmail Hakkı Bey’e verdiği 1917 tarihli bir talimat dikkat çekicidir. ${ }^{75}$ Rahibe yazısında, yükselen fiyatlar nedeniyle hükümetin ayırdığı bütçenin yetimhanenin ihtiyacını karşılamadığından, yetim sayısının yüzü aştığı için günlük gıda temininin dahi tedarik edilemediğinden bahsetmekte; çözümler aranmasını talep etmekteydi. ${ }^{76}$ Nezâret'e verilen dilekçenin arkasına düşülen notta, her ay Mâliye Hazinesi'nden yetimhaneye aktarılan bütçeye yönelik inceleme yapıldığı belirtilmiş ve söz konusu bütçenin arttırılması istenmişti. ${ }^{77}$ Son olarak Dâhiliye Nezâreti İdare-i Umumiye-i Dâhiliye Müdüriyeti'nden çıkan evrakta, Nazır Talat Paşa konu hakkında İaşe-i Umumiye Müdürü İsmail Hakkı Bey’e mümkün olan yardımların yapılması yönünde talimat vermişti. ${ }^{78}$ Yetimhaneye ayrılan maliye bütçesinin arttırılmasına yönelik aynı talep, Patrik Vekili Serpiskopos Kapriel Cevahirciyan imzasıyla Ermeni Gatoğigosluğu ${ }^{79}$ ve Patrikliği tarafından da 21 Ağustos 1917 tarihli resmî bir yazı ile Adliye ve Mezâhib Nezâreti'ne iletilmişti. ${ }^{80}$ Patrikliğin evrakı iki gün sonra aynı içerikle Adliye ve Mezâhib Nezâreti'nden Sadrazam' a ${ }^{81}$ ve Mâliye Nezâreti'ne ${ }^{82}$ sevk edilmişti. ${ }^{83}$

1917 yılında iaşelerin teminine dair sıkıntıları hafifletebilmek maksadıyla yetimhane yöneticileri, Amerikan Misyoner Teşkilatı'nın Hasköy gibi bazı semtlerde uyguladığı yoksullara yemek yapım-dağıtım çalışmalarına iki sene boyunca katılımış, bu sayede haftalık iki-üç kez yemeklerden yetimler de faydalanmışlard1. ${ }^{84}$

Gatoğigos ve Patrik Vekili Episkopos Kapriel Cevahirciyan, Baş Rahibe ve çalışma arkadaşlarına yetimlerin bakımı ve eğitimlerini karşılayabilmek için gösterdikleri çaba neticesinde Diyakoz [Sargavak] rütbesini İstanbul'da ilk kez rahibelere bahşederek, ayinlerde görev yapabilme yetkisi tanımıştı. Cevahirciyan, ayrıca 14 Şubat 1918 günü yetimhanenin şapelini Surp Asdvadzadzin adına kutsayarak şapelde Badarak Ayini ${ }^{85}$ yapılmasına izin vermişti. ${ }^{86}$

74 BOA.DH.I.UM.EK.38.75.2.1 (Tarih: R. 12 Ağustos 1333/M. 12 Ağustos 1917).

75 BOA.DH.I.UM.EK.38.75.1.1 (Tarih: R. 2 Eylül 1333/M. 2 Eylül 1917).

76 BOA.DH.I.UM.EK.38.75.2.1 (Tarih: R. 12 Ağustos 1333/M. 12 Ağustos 1917).

77 “(...) tahsisât-1 mesbûtanın mâh mâh hazîne-i mâliyeden alındığı ve maksad-1 mürâca'atın bunun tezyidini istirhamdan ibâret oldığı (...)”. BOA.DH.I.UM.EK.38.75.2.2 (Tarih: R. 1 Eylül 1333/M. 1 Eylül 1917).

78 BOA.DH.I.UM.EK.38.75.1.1 (Tarih: R. 2 Eylül 1333/M. 2 Eylül 1917).

79 Gatoğigos; Ermeni Kilisesi hiyerarşisi içinde en yüksek ruhani olup Ermeni Başpatriklerine verilen unvandır.

80 BOA.BEO.4482.336082.2.1 (Tarih: R. 21 Ağustos 1333/M. 21 Ağustos 1917).

81 BOA.BEO.4482.336082.3.1 (Tarih: R. 23 Ağustos 1333/M. 23 Ağustos 1917).

82 BOA.BEO.4482.336082.1.1 (Tarih: R. 25 Ağustos 1333/M. 25 Ağustos 1917).

83 Talebin sonucuna dair başka bir bilgi bulunmamaktadır.

84 İki sene boyunca toplamda 137 defa 700 kişilik 100,000 porsiyon yemek pişirilmiştir (Çınar, Erziyan, a.g.e., s.40).

85 Ermeni Kilisesi'nin en önemli ve en uzun ayini olan 'Badarak' 1 kelime anlamı 'Rabbin Sofrası'dır. 'Kudas-1 Şerif' ya da 'Kutsal Sunu' olarak da bilinen ayinde Hz. İsa'nın son akşam yemeği esnasında kutsadığı ekmek ve şarabı, havarilerine kendi kanı ve bedeni olarak sunması anlatılmaktadır. Katoliklerin Ökaristi/Mas Ayini'dir.

86 Varjabedyan, a.g.e., s.83-84. 
Baş Rahibe Kristine, görevini on yedi y1l sürdürdükten sonra 12 Temmuz 1919 tarihinde vefat etmiş, cenazesi Surp Asdvadzadzin Şapeli'nde yapılan merasim sonrası yetimhanenin bahçesine gömülmüştü. ${ }^{87}$ Yerine görevi devralan Rahibe Köseyan döneminde yetimhane, yeniden büyük onarımlar geçirmiş, yeni bölümler eklenmesi için hükümetten izinler alınmıştı.

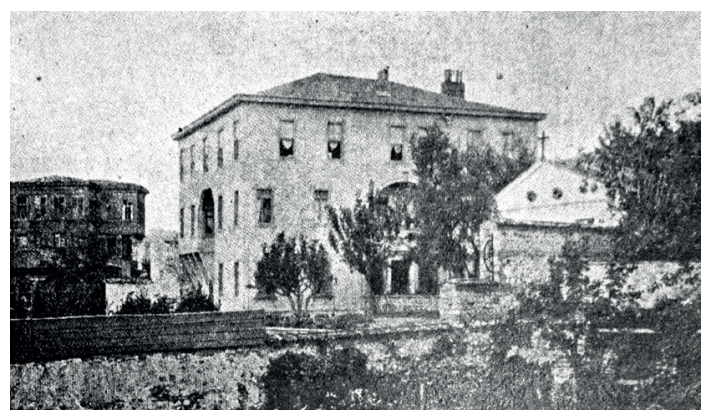

F. 5: Kalfayan Kızlar Yetimhanesi ve Şapeli (Tuğlac1, 2004, s.257.)

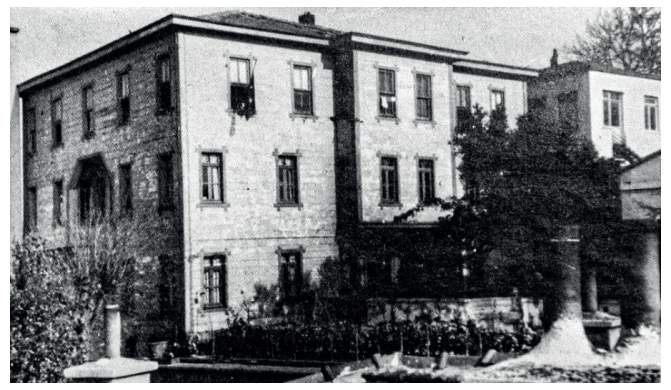

F. 6: Kalfayan Kızlar Yetimhanesi binasının son dönemleri (Çınar, Erziyan, 1966, s. no yok.)

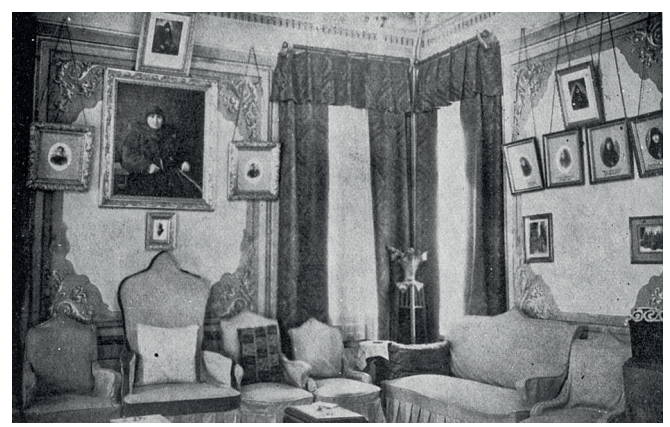

F. 7: Kalfayan Kizlar Yetimhanesi'nin Misafirhanesi (Çınar, Erziyan, 1966, s. no yok.) 


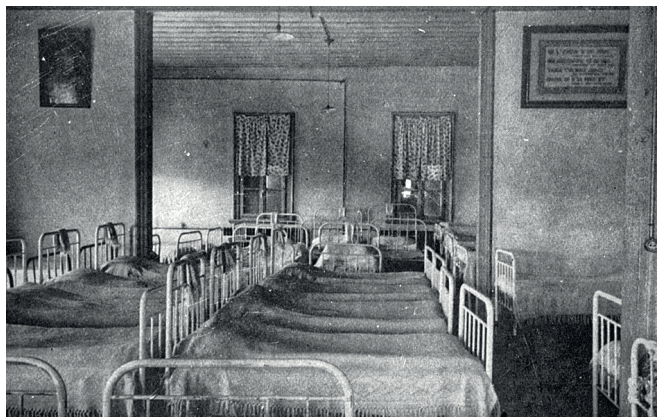

F. 8: Kalfayan Kızlar Yetimhanesi'nin Yatakhanesi (Çınar, Erziyan, 1966, s. no yok.)

Cumhurbaşkanlığı Osmanlı Arşivi'nde rastlanılan bir belgeye göre Hasköy’de Peştemalcı Sokağı'ndaki Kalfayan Kız Yetimhanesi'ne ait arsaya bir bina inşası söz konusu olmuştu. Bu yapı inşasına ilişkin inceleme yapmak üzere fenn-î heyet oluşturulması talebi, Dâhiliye Nezâreti İdare-i Umumiye ve Dâhiliye Müdüriyeti'nden, Şehremâneti Heyet-i Fenniye Müdüriyeti’ne yazılı olarak iletilmişti. ${ }^{88}$ Daha sonra, oluşturulan fenn-î heyet, adı geçen adrese giderek gerekli incelemeleri yapmış, ${ }^{89}$ yapımı tasarlanan binanın öğretmenlerin ikâmetine yönelik bir lojman olacağını ve bunun yetimhane bahçesine inşa edileceğini belirtmişti. Yetimhane idaresi, "Hasköyde Peştamalcı zukağında 1, 3, 5 ve 7" numarada bulunan "Meryem ana ermeni inâs mektebi eytâmhânesi arsasına" yapılacak ev için ruhsat talebinde bulunmuş; dilekçeye binanın proje, resim, harita ve diğer evraklarını da ekleyerek Şehremâneti'ne göndermişti. ${ }^{90}$ Bu talebin incelenerek, 12 Haziran 1911 yılında çıkarılmış genel bir tebligatın ekindeki talimatname hükümlerine uygun olarak yapı inşa talebinin sonuçlandırılması ve sonucunun bildirilmesi istenmişti. ${ }^{11}$ Aynı yıl Ermeni Patrikliği tarafından lojman inşaatına dair hazırlanan üç proje ile birlikte yetimhane tapusunun bulunduğu dosya ilgili makamlara gönderilerek, önceki evraklara eklenmişti. ${ }^{92}$ İnşası için ruhsat verilmesi istenen bina hakkında gereğinin yapılması için Şurâ-yı

88 BOA.DH.I.UM.7.8.1.22.5.1 (Tarih: R. 9 Mayıs 1338/M. 9 Mayıs 1922) Şehremânetine yazılan aynı içerikteki evrak müsvedde belgesi için bkz. BOA.DH.I.UM.7.8.1.22.1.2 (Tarih: R.8 Mayıs 1338/M. 8 Mayıs 1922).

89 Şehremâneti Fenn-î Heyeti müzekkeresi için bkz. BOA.DH.I.UM.7.8.1.22.1.3 (Tarih: R. 9 Mayıs 1338/ M. 9 Mayıs 1922) ve BOA.DH.I.UM.7.8.1.22.2.2 (Tarih: R. 21 Mayıs 1338/M. 21 Mayıs 1922); Hazırlanan bu müzekkere daha sonra Şehremâneti Heyet-i Fenniye Müdüriyeti’nden Dâhiliye Nezâreti İdare-i Umumiye ve Dâhiliye Müdüriyeti’ne gönderilmiştir. Bkz. BOA.DH.I.UM.7.8.1.22.4.1 (Tarih: R. 6 Haziran 1338/M. 6 Haziran 1922).

90 Tasniften bahsi geçen plan, proje, resim ve harita gibi bir varak çıkmamıştır. BOA.DH.I.UM.7.8.1.22.6.1 (Tarih: R. 17 Mayıs 1338/M. 17 Mayis 1922).

91 “(...) 30 Mayıs (1)327 tarihli tebligât-1 'umûmiyeye merbut ta'limâtnâme ahkâmına tevfikan mu'amele-i mukteziyenin ifâsı ve neticenin inbâsı”. BOA.DH.I.UM.7.8.1.22.2.1 (Tarih: R. 20 Mayıs 1338/M. 20 Mayıs 1922).

92 BOA.ŞD.2848.17.1 (Tarih: R. 12 Ağustos 1338/M. 12 Ağustos 1922). Tasnifteki bu belge, konuyla ilgili Divan-1 Hümâyûn Beylikçiliği Kalemi'ne sunulacak evrakların listesini göstermektedir. Lojman inşasıyla ilgili Patrikhane tarafından üç proje hazırlatılıp ilgili makamlara sunulduğu bilgisine, bu listedeki verilerden ulaşılabilmektedir. Ayrıca listede belirtilen evrakların çıkış yerlerine bakılırsa yazışmalar, Ermeni Patrikliği, Adliye ve Mezâhib 
Devlet'e havale edilen yazı, Divan-1 Hümayun Beylikçiliği'ne sunulmuştu. ${ }^{93}$ Buradan çıkan yazı ve ekleri, diğer başka kalemlere gönderilmiş, beylikçilikten çıkan yazının içeriğine göre gereğinin yapılması ve sonucunun bildirilmesi istenmişti. ${ }^{94}$

Belge tasnifleri içinde, yetimhane bahçesine bahsi geçen lojmanın inşa edilip edilmediğine dair bir belge/bilgi bulunmamakla birlikte, Ermenice kaynaklardan, oluşturulan bir inşa fonuyla 16,000 liralık bağış toplandığı ve bu sayede 1924 yılında yetimhanenin ana binasına üçüncü bir katın çıkıldığı, şapelin onarılarak genişletildiği, elektrik sisteminin döşendiği öğrenilmektedir. Binanın 1924'ten sonraki yıllara ait fotoğraflarından inşa malzemesinin ahşap olduğu anlaşılan köşkün, muhtemelen ana girişinin de yer aldığ 1 şapele bakan cephesinin içe çekilmiş eyvanımsı düzenlemesinin de değiştirilerek iki pencereli düz bir çıkma/cumba şeklinde öne çekildiği görülmektedir (F.5, 6, 7, 8)..$^{95}$

14 Haziran 1928 tarih ve 341 numaralı ruhsatname ile Maârif Vekâleti'ne bağlı bir ilköğretim okulu statüsü alan Kalfayan Kız Yetimhanesi, 1969 yılında çıkan karar sonrası, Surp Nersesyan Mektebi gibi, istimlak kapsamına alınıp yıktırılınca kurum, daha önce yazlık olarak kullandığ Üsküdar Altunizade'deki Toprak Sokak No: 26'ya ${ }^{96}$ taşınmıştı. 2000 yılında Üsküdar'daki Semerciyan-Cemaran İlkokulu'yla birleştirilen yetimhane bugün Kalfayan İlköğretim Okulu adı altında eğitime devam etmekte, barınma ise yazlık binada yapılmaktadır.

\section{Nubar-Şahnazaryan Mektebi}

Hasköy'deki bir diğer eğitim kurumu olan Nubar-Şahnazaryan Mektebi; filolog, yayımcı ve eğitimci Garabed Vartabed ${ }^{97}$ Şahnazaryan $^{98}$ (1814-1865) tarafindan kurulmuştu (F.9). 1865 'te İstanbul'a yerleşen Vartabed Şahnazaryan, Ermeni Kilisesi'ne din adamı yetiştirmek üzere Kilikya'da bir teoloji okulu açmayı arzu etmiş ve bu vasiyetini ölümünden bir gün önce,

Nezâreti, İstanbul Şehremâneti, Beyoğlu Mutasarrıflı̆̆ı, Beyoğlu İdari Şubeler Müdürlüğü, İstanbul Valiliği ve Dâhiliye Nezâreti arasında yapılmaktadır. Yetimhane tapusu ise listede "Sened-i Hâkânî Sûretî” olarak geçmektedir. Divan-1 Hümâyûn Beylikçiliği'ne verilmek üzere hazırlanan belgeler Müsteşarlık makamına verilmiştir. Bkz. BOA.ŞD.2848.17.2 (Tarih: R. 12 Ağustos 1338/M. 12 Ağustos 1922).

93 "Hasköyde Meryem ana nam-1 diger Kalfayân inâs eytâmhânesi ittisalindeki 'arsalar üzerine inşasına ruhsat i'atâsı istid'â olnan binâ hakkında 'adliye ve mezâhib nezâretinin şura-yı devlete havale ve muktezasının beyânı zımnında bi’t-takdîm divân-1 hümâyûn begligciliginin 27 Agustos 1338 tarihli müzekkeresi ile i'âdeten tevdi’ buyrılân tezkeresi ile melfûfâtı mülkiye ve ma'ârif dâiresinde lede'l-kıraa begligciligin müzekkeresi mündericatına nazarân muktezasının îfâsıyla neticesinin inbâsı içün (...)”. BOA.ŞD.2848.17.6 (Tarih: R. 24 Eylül 1338/M. 24 Eylül 1922).

94 ŞD.2848.17 no.lu bu tasnifte, Beylikçilik’ten çıkan yazı bulunmadığından, yazı içeriğine ulaşılamamıştır.

95 Çinar, Erziyan, a.g.e., s.44.

96 Şimdiki Yetimhane Sokağı.

97 'Başrahip' anlamına gelen, bekârlık yemini etmiş din adamı.

9814 Mayıs 1814 tarihinde İran'ın Hamadan kentinde dünyaya gelen Şahnazaryan, Eçmiadzin’de eğitim görmüş ve orada rahip takdis edilmişti. 1849 yılında İstanbul'a gelen Vartabed, önce Galata'daki Surp Lusavoriç Ermeni Kilisesi'ne daha sonra da Hasköy'deki Surp Istepanos Ermeni Kilisesi'ne vaiz tayin edilmişti. 1855'te önce Paris'e, 1862'de ise Manchester'a geçerek, dergiler çıkarmış, matbaalar tesis etmişti. 1865 yılında hastalığı sebebiyle İstanbul'a dönerek Hasköy'de ikâmet etmeye başlasa da 31 Ağustos'ta vefat etmiş, Hasköy Ermeni Mezarlığı'ndaki Cezayirliyan Ailesi'nin kabristanına gömülmüştü (S. Kulamiryants, “Garabed Vartabed Şahnazaryants", Araks, S.3, St. Petersburg, 1889, s.59-71). 
yakın zamanda Mısır'a yola çıkacak olan Episkopos Nerses Varjabeyan'a teslim ederek Mısır Ermenilerinden devlet adamı Nubar Paşa Nubaryan'a (1825-1899) iletmesini rica etmişti. ${ }^{99}$

Varjabeyan ve Nubar Paşa, Vartabed'in vasiyetinin Kilikya yerine Hasköy'de gerçekleşmesinin daha doğru olacağını düşünerek, ahşap bir binada, orta dereceli ve yatılı olan Nubar-Şahnazaryan Mektebi'ni faaliyete geçirmişlerdi. ${ }^{100}$ Nubar Paşa tarafından 4000 altın hibe ile tesis edilen okul, on yıl süre ile döneminin ünlü hocaları bünyesinde barındırarak semtin önemli eğitim kurumlarından biri olmuştu. Yetiştirdiği üç yüz kadar öğrenci arasında Ermeni entelektüel aydınlanmasının önemli isimlerinden eğitimci, pedagog, prestijli Ermeni Berberyan Okulu'nun kurucusu Reteos Berberyan (1850-1907); yazar Yeğya Demircibaşyan (1848-1908); yazar, gazeteci, eğitimci ve tercüman Minas Çeraz (1852-1929); yazar, hukukçu, İstanbul mebusu Krikor Zohrab (1861-1915) ve daha birçok kişi bulunmaktayd. ${ }^{101}$

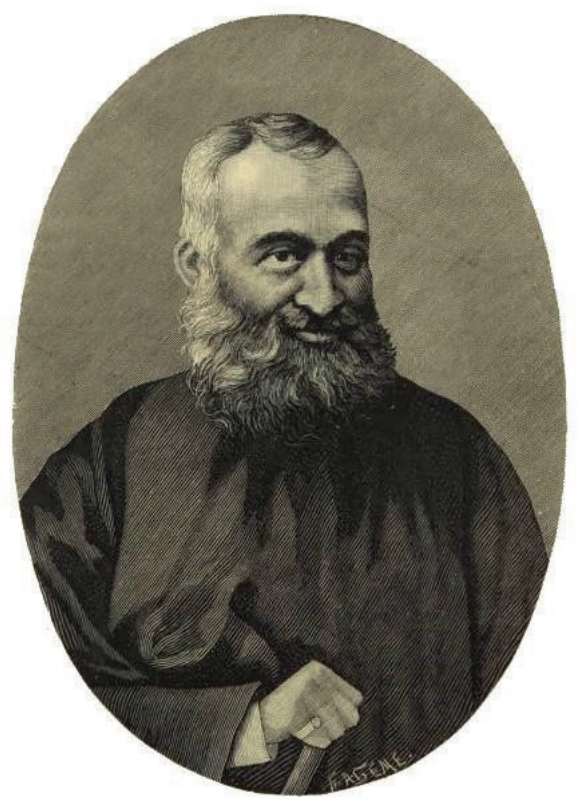

F. 9: Garabed Vartabed Şahnazaryan (1814-1865)

(Kulamiryants, 1889, s.58.)

99 Zartaryan, a.g.e., s.28-31.

100 Kulamiryants, a.g.m., s.72.

101 Varjabedyan, a.g.e., s.91, 222. 
Vasiyet edenin arzusu doğrultusunda, Vartabed'in Manchester'da kullandığı matbaa makineleri 1870'te Nubar-Şahnazaryan Mektebi'ne taşınmış, aynı yıl talebelerin hazırladığı Yergrakunt [Yerküre] adlı dergi basılmıştı. Okulun kapanış tarihine kadar yaklaşık iki yıl faaliyet gösteren matbaa, daha sonra Asiagan Ingerutyun'un [Asya Cemiyeti] bünyesinde devam etmişti. ${ }^{102}$

Açılışından kısa bir süre sonra bünyesindeki en başarılı öğrenciler Surp Nersesyan Mektebi’ne naklolunca okulun malî durumu kötüleşmişti. Osmanlı devlet tahvili gelirlerinin ani düşüşü ise son darbe olmuş, parlak bir dönemin ardından okul kapatılmıştı. Patrik Nerses tekrar açmak için hayli gayret sarf etse de başarılı olamamıştı. Nubar-Şahnazaryan Mektebi’nin kapanışından sonra bina uzunca süre fakirhane olarak kullanılmış, Patrikhane'nin “Ekonomi Komisyonu”nun kararıyla 1886 yılında harap olduğu gerekçesiyle yıktırılmış, arsası ise boş kalmıştı. ${ }^{103}$

\section{Sonuç}

19. yüzyılın başından itibaren İstanbul Ermenilerinin modernleşme tecrübesi içerisinde merkezî konumdaki semtlerden biri olan Hasköy’ün başat özelliğinin eğitime verdiği önem ve bu alanda gerçekleştirdiği yapılaşma faaliyetleri olduğu görülmektedir.

Hasköy'deki eğitim yapılarının entelektüel misyonuna atfedilen önemin somut formlara dönüşmesi adına en büyük çabayı sarf edenlerin başında sivil mesenler -özellikle de maddî açıdan bulundukları katkılarla kimi amiralar- ile aydın din adamları gelmektedir. İlerleyen dönemlerde seküler eğitime verilen değerin artmasıyla birlikte çeşitlenen tüm bu destekçiler semtin eğitim yapılarını, kilise dahilindeki bir odada verilenin ötesine taşıyarak, kitlesel ve modern eğitime hizmet verebilecek ölçek ve yapıdaki mimarî örneklere dönüştürmüşlerdir.

Gelişmeler doğrultusunda gereksinimleri karşılayacak şekilde inşa ve/veya tadil edildiği anlaşılan Hasköy'deki eğitim yapılarının belirli bir tipolojiye sahip olmayarak hem yüzyılın mimarî repertuarına uygun Neoklasik üslûpta kârgir malzeme ile hem de geleneksel ahşap konut tipinde olması, tercihten ziyade kendisini oluşturan malî gücün getirdiği şartlardan ileri gelmektedir. Anlaşılan odur ki amaç mimarî bir temsilden ziyade kültürel hafızanın nesillere aktarılabileceği bir mekâna sahip olmaktır.

Hakem Değerlendirmesi: Dış bağımsız.

Çıkar Çatışması: Yazar çıkar çatışması bildirmemiştir.

Finansal Destek: Yazar bu çalışma için finansal destek almadığını beyan etmiş̧ir.

Peer-review: Externally peer-reviewed.

Conflict of Interest: The author has no conflict of interest to declare.

Grant Support: The author declared that this study has received no financial support.

102 Kulamiryants, a.g.m., s.73.

103 Varjabedyan, a.g.e., s.92, 222. 


\section{Kaynakça/References}

Alboyacıyan, Arşag, “Azkayin Sahmanatrutyunı, İr Dzakumı Yev Girargutyunı” [Millî Nizamname, Başlangıcı ve Tatbiki], Intartsag Oraytsuyts Azkayin Hivantanotzi 1910 [Ermeni Hastanesi Mufassal Takvimi], H. Madteosyan Matbaas1, İstanbul, 1910, s.76-528.

Alboyacıyan, Arşag, "Gırtagan Hisnamyag Mı (1853-1903)" [Eğitimde Elli Yıl], Püzantion, 27 Ekim 1903, s.1 Anonim, Jamanak, 21 Temmuz 1964, s. 4.

Anonim, "Usumnagan Khorhurt" [Maârif Komisyonu], Arpi Araradyan, S.6, İzmir, Aralık 1853, s.73-74.

Anonim, “Azkayin Joğov Hayots” [Millî Ermeni Meclisi], Dzrakir Inthanur Orinats Azkayin Gırtutyan [Millî Eğitim Programı], M. Sarıan, İstanbul, 1881.

Anonim, Azkayin Sahmanatrutyun Hayots [Nizâmnâme-i Milleti Ermeniyân], Mühendisyan Matbaası, İstanbul, 1863.

Anonim, Keğuni, S.1, Venedik, 1 Aralık 1901, s. 6.

Anonim, Vatsunamyag Kalfayan Ağçıants Vorpanotsi, Hasküğ (1886-1926) [Kalfayan Kız Yetimhanesi'nin 60. Yıldönümü, Hasköy], H. M. Setyan Matbaası, İstanbul, 1926.

Artinian, Vartan, Osmanlı Devleti'nde Ermeni Anayasası'nın Doğuşu 1839-1863, Çev. Zülal Kılıı̧, Aras Yayınc1lık, İstanbul, 2004.

Barsoumian, Hagop L., İstanbul'un Ermeni Amiralar Sınıfi, Çev. Solina Silahlı, Aras Yayıncılık, İstanbul, 2013.

BOA.BEO, 3425.256828.2.1, 18 Teşrinievvel 1324, 31 Ekim 1908; 3425.256828.3.1, 9 Teşrinisâni 1324, 22 Kasım 1908; 3734.280039.1.1, 5 R 1328, 16 Nisan 1910; 3734.280039.2.1, 1 R 1328, 12 Nisan 1910; 4081.306069.1.1, 25 N 1330, 7 Eylül 1912; 4482.336082.1.1, 25 Ağustos 1333, 25 Ağustos 1917; 4482.336082.2.1, 21 Ağustos 1333, 21 Ağustos 1917); 4482.336082.3.1, 23 Ağustos 1333, 23 Ağustos 1917.

BOA.DH.I.UM, 7.8.1.22.1.2, 8 Mayıs 1338, 8 Mayıs 1922; 7.8.1.22.1.3, 9 Mayıs 1338, 9 May1s 1922; 7.8.1.22.2.1, 20 Mayıs 1338, 20 Mayıs 1922; 7.8.1.22.2.2, 21 May1s 1338, 21 May1s 1922; 7.8.1.22.4.1, 6 Haziran 1338, 6 Haziran 1922; 7.8.1.22.5.1, 9 Mayıs 1338, 9 Mayıs 1922; 7.8.1.22.6.1, 17 May1s 1338, 17 May1s 1922.

BOA.DH.I.UM.EK, 38.75.1.1, 2 Eylül 1333, 2 Eylül 1917; 38.75.2.1, 12 Ağustos 1333, 12 Ağustos 1917; 38.75.2.2, 1 Eylül 1333, 1 Eylül 1917.

BOA.İ.AZN, 57.8.1.1, 8 Temmuz 1320, 21 Temmuz 1904; 57.8.2.1; 57.8.4.1, 4 Ağustos 1320, 17 Ağustos 1904.

BOA.MF.MKT, 776.48.1.1, 8 S 1322, 24 Nisan 1904; 776.48.1.2, 12 S 1322, 28 Nisan 1904; 776.48.2.2, 16 S 1322, 2 May1s 1904; 805.64.1.1, 15 Ağustos 1320, 28 Ağustos 1904.

BOA.ŞD, 195.16, 7 Ra 1328, 19 Mart 1910; 2739.7.1.1; 2739.7.2.1, 26 Nisan 1320, 9 Mayıs 1904; 2739.7.3.1, 5 Mayıs 1320, 18 Mayıs 1904; 2739.7.4.1, 6 Mayıs 1320, 19 Mayıs 1904; 2739.7.5.1, 10 Mayıs 1320, 23 May1s 1904; 2739.7.6.1, 12 Mayıs 1320, 25 May1s 1904; 2848.17.1, 12 Ağustos 1338, 12 Ağustos 1922; 2848.17.2, 12 Ağustos 1338, 12 Ağustos 1922; 2848.17.6, 24 Eylül 1338, 24 Eylül 1922.

BOA.Y.PRK.ZB, 34.59.1.2, 4 S1322, 20 Nisan 1904.

Çeraz, Minas, Azkayin Tasdiaragutyun: Varjabedagan Joğovi meç Khosuadz Carer [Millî Eğitim: Maârif Toplantısından Nutuklar], Aramyan Matbaası, İstanbul, 1873.

Çınar, Hagop; Erziyan, Berç, Harüramya Hişadagaran Kalfayan Dan, 1866-1966 [Kalfayan Evi'nin 100. Y1l Anı Kitab1], A. H. Matbaası, İstanbul, 1966.

Dadyan, Saro, Osmanlı'da Ermeni Aristokrasisi, Everest Yayınları, İstanbul, 2011. 
Ergin, Osman, Türk Maarif Tarih, C.I-II, Eser Matbaası, İstanbul, 1977.

Keçyan, Püzant, Badmutyun Surp Pırgiç Hivantanotsin Hayots Gosdantinobolis, Azkayin Hüsnamya

Nıgarakir [İstanbul Surp Pırgiç Ermeni Hastanesi’nin Tarihi], K. Bağdadlıyan Matbaası, İstanbul, 1887.

Kemahlı Krikor, Jamanagakrutyun [Kronoloji], Haz. Mesrop Nışanyan, Ermeni Apostolik Kilisesi S. Hagop

Matbaas1, Kudüs, 1915.

Kılıç, Davut, Osmanlı İdaresinde Ermeniler Arasındaki Dinî ve Siyasi Mücadeleler, Avrasya Stratejik

Araştırmalar Merkezi Yayınları, Ankara, 2000.

Kömürcüyan, Eremya Çelebi, İstanbul Tarihi, XVII. Asırda İstanbul, Çev. Hrans D. Andreasyan, Haz.

Kevork Pamukciyan, Eren Yayıncılık ve Kitapçılık, 1988.

Kulamiryants S., “Garabed Vartabed Şahnazaryants”, Araks, S.3, St. Petersburg, 1889, s.58-75.

Malhasyan, Silvart, “Odyan, Krikor”, Osmanlılar Ansiklopedisi, Yaşamları ve Yapıtlarıyla, C.II, Der. Ekrem Işın, İsmail Kara, Yapı Kredi Yayınları, İstanbul, 2008, s.375-379.

Manav, Nursel, Zenginlikten İflasa Mustafa Reşid Paşa’nın Sarrafı Cezayirlioğlu Mıgırdiç, Libra Kitap, İstanbul, 2019.

Nalbandian, Louise, The Armenian Revolutionary Movement, The Development of Armenian Political

Parties through the Nineteenth Century, University of California Press, 1963.

Ormanyan, Mağakya, Azkabadum [Milletnâme], C.III, Surp Hagopyants Matbaası, Yerusalem, 1927.

Ormanyan, Mağakya, Kho yev Khosk [Tefekkür ve Söz], Hagopyan Matbaası, Yerusalem, 1929.

Palakaşyan, Hovnan, “Hişadagneres Badarig Mı” [Anılarımdan Küçük Bir Parça], Jamanak, 15 Eylül 1926, s.3.

Sarraf, Talin, “Bir Zamanlar Okuldu: Haliç Köprüsüne Kurban Gitti”, Agos, İstanbul, 10 Ocak 1997, s.3.

Strong, William E., The Story of the American Board: An Account of the First Hundred Years of the American Board of Commissioners for Foreign Missions, Boston, Pilgrim Press, 1910.

Todün, "Krikor Baronderi Hişadagaranı, Balati S. Hıreşdagabed Yegeğetsiin Artiv” [Krikor Baronder'in Anıları, Balat'taki Surp Hıreşdagabed Kilisesi Vesilesiyle], Panaser, C.II, S.3-4, 1901, Paris, s. 148-152.

Tuğlacı, Pars, Tarih Boyunca Batı Ermenileri, C.II, Pars Yayın ve Ticaret, İstanbul, 2004.

Varjabedyan, Hagop, Hişadagaran Harüramya Hopelyani Khasküği S. Istepanos Yegeğetsvo, 1831-1931

[Hasköy Surp Istepanos Kilisesi Yüzüncü Yıl Anı Kitab1], H. M. Setyan Matbaası, İstanbul, 1931.

Zartaryan, Vahan, Hişadagaran, Hay Yerevelineru Gensakrutyunnerı, Lusanıgarnerı, Tzerakirneri,

Krutyunnerı Yevayln 1512-1912 [Hatırat, Ünlü Ermenilerin Biyografileri, Fotoğrafları, El Yazmaları, Yazıları vs.], C.II, Nışan-Babigyan Matbaası, İstanbul, 1910. 
